\title{
Carbon nanomaterials: production, impact on plant development, agricultural and environmental applications
}

\author{
Olga Zaytseva* and Günter Neumann
}

\begin{abstract}
During the relatively short time since the discovery of fullerenes in 1985, carbon nanotubes in 1991, and graphene in 2004, the unique properties of carbon-based nanomaterials have attracted great interest, which has promoted the development of methods for large-scale industrial production. The continuously increasing commercial use of engineered carbon-based nanomaterials includes technical, medical, environmental and agricultural applications. Regardless of the application field, this is also associated with an increasing trend of intentional or unintended release of carbon nanomaterials into the environment, where the effect on living organisms is still difficult to predict. This review describes the different types of carbon-based nanomaterials, major production techniques and important trends for agricultural and environmental applications. The current status of research regarding the impact of carbon nanomaterials on plant growth and development is summarized, also addressing the currently most relevant knowledge gaps.
\end{abstract}

Keywords: Carbon-based nanomaterials, Carbon nanotubes, Fullerenes, Graphene, Germination, Plant development, Agricultural application

\section{Introduction}

Some chemical elements are able to compose a range of different molecular structures from the same type of atoms-a unique feature known as "allotropy". Different chemical and physical properties of those materials are determined by the structural geometry of the atoms and the type of chemical bounds within the molecules. In this context, carbon is one of the most interesting elements, with the ability to form a wide range of structures, frequently with fundamentally different properties. Classical examples of carbon allotropes comprise "hard" diamond and "soft" graphite used in science and technology and in a wide range of products, including consumer goods in various areas of human activity [1].

The list of known carbon allotropes has expanded during the last decades of the 20th century after the discovery of several new low-dimensional carbon forms. The novel materials comprised carbon nanotubes (CNTs),

\footnotetext{
*Correspondence: olga.zaytseva@uni-hohenheim.de

Institute of Crop Science (340 h), Hohenheim University, Fruwirtstrasse 20, 70593 Stuttgart, Germany
} (0)

fullerenes and graphene and attracted high interest from science and industry, since these materials exhibited a wide range of outstanding and novel features as promising materials for numerous application fields. Based on these properties, they were repeatedly termed as "wonder materials" in the scientific literature [2-5].

Natural carbon-based nanoparticles exist only in negligible quantities, and the overwhelming majority are engineered, or artificially synthesized. Therefore, their availability does not depend on natural reserves (such as diamonds), and theoretically production can be performed in unlimited quantities as long as raw materials for synthesis are available. According to latest forecasts, a constant increase of production volumes is expected during the next decade [6, 7]. However, despite the fact that carbon-based nanomaterials promote industrial progress there are concerns about a potential release into the environment and interactions of released nanomaterials with living organisms and incorporation into food chains with unknown consequences.

In the face of the increasing importance of practical applications, this review will focus on two major aspects 
associated with the handling of carbon-based nanomaterials considering:

1. Production and potential applications, with special focus on the environmental and agricultural sectors, and the significance for the improvement and development of novel, efficient products and technologies;

2. Potential impact on living organisms with a special focus on plants, as a fundamental component of food chains in natural and agricultural ecosystems, where increased input of carbon nanomaterials can be expected as a consequence of intentional use in agricultural and environmental applications or by accidental release as unintended contamination.

\section{Classification of carbon-based nanomaterials}

Carbon is one of the few chemical elements (including also silicone) with the ability to polymerize at the atomic level, thus forming very long carbon chains. Due to the four electrons in the outer electron layer (Fig. 1a, b), carbon atoms have a valence of four and can be linked via single, double or triple covalent bonds, or also with other elements. These properties of carbon atoms can be attributed to their special electron structure and the smaller size compared with other elements of group IV.

For the reasons specified above, carbon can exist in a range of different molecular forms, composed by the same type of atoms but due to different structures, possessing different properties. These forms are termed as "allotropes" or "allotropic modifications" of a certain chemical element. Until recently, only two natural carbon allotropes were known: diamond and graphite. Meanwhile, various new allotropic forms have been described, including carbon nanomaterials. In general, nanomaterials are defined as materials containing particles with at least one dimension between 1 and $100 \mathrm{~nm}$ in size [8]. All nanomaterials composed of carbon atoms are termed as carbon-based or carbon nanomaterials. Classification of carbon-based nanomaterials is most commonly performed according to their geometrical structure. Carbon nanostructures include particles which can be tubeshaped, horn-shaped, spherical or ellipsoidal. Nanoparticles having the shape of tubes are termed as carbon nanotubes; horn-shaped particles are nanohorns and spheres or ellipsoids belong to the group of fullerenes. In the meantime, carbon nanomaterials have numerous

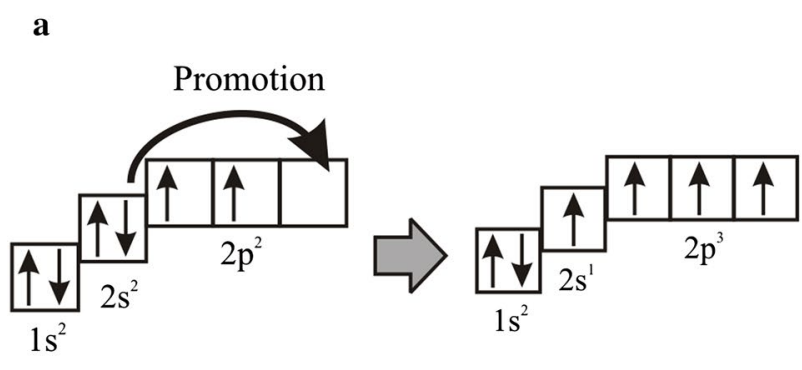

b

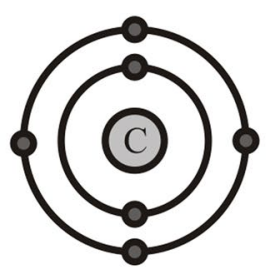

e

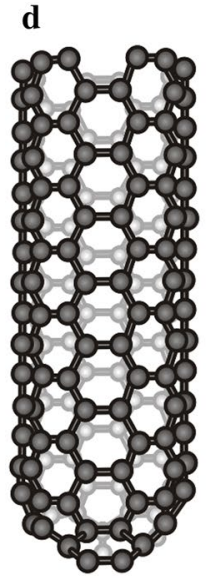

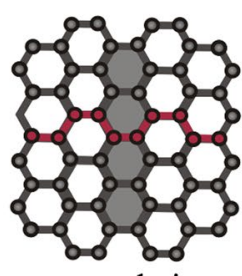

armchair

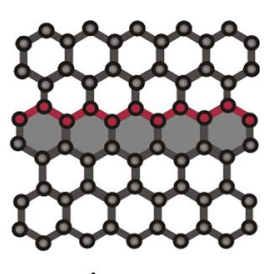

zig-zag

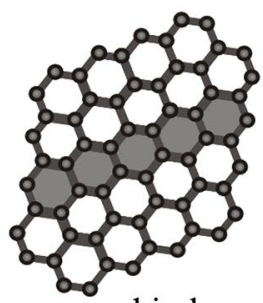

chiral

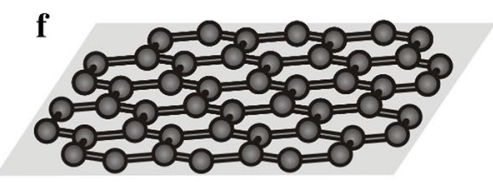

c

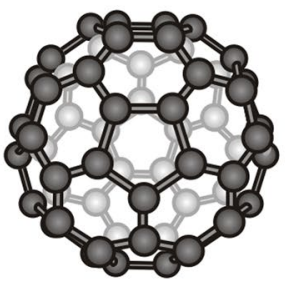

g

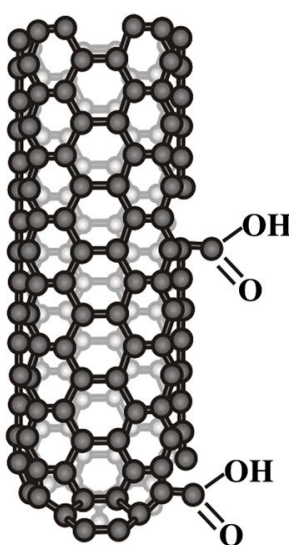

Fig. 1 Structure of a carbon atom and of carbon-based nanoparticles. a Electrone configuration of a carbone atom before and after promotion of one s-electrone; $\mathbf{b}$ schematic representation of a carbon atom structure with two electron orbtales arownd the nucleus and six electrones distributed on them; c structure of a fullerene $\mathbf{C 6 0} ; \mathbf{d}$ structure of a single-walled nanotube; $\mathbf{e}$ different types of single-walled nanotubes: armchair, zig-zag and chiral; $\mathbf{f}$ structure of a graphene sheet; $\mathbf{g}$ structure of an oxidazed single-walled nanotube 
technical applications including micro- and nanoelectronics, gas storage, production of conductive plastics, composites, displays, antifouling paints, textiles, batteries with improved durability, gas biosensors and others [9-11].

\section{Fullerenes}

Fullerenes are an allotropic modification of carbon, often termed as a molecular form of carbon, or carbon molecules. Fullerenes were discovered in 1985 by H.W. Kroto, R.F. Curl and R.E. Smalley [12] who were later awarded with the nobel prize for chemistry in 1996. The fullerene family includes a number of atomic $C_{n}$ clusters $(n>20)$, composed of carbon atoms on a spherical surface. Carbon atoms are usually located on the surface of the sphere at the vertices of pentagons and hexagons. In fullerenes, carbon atoms are usually present in the $\mathrm{sp}^{2}$-hybrid form and linked together by covalent bonds. Fullerene C60 is the most common and best-investigated fullerene. The spherical molecule is highly symmetric and consists of 60 carbon atoms, located at the vertices of twenty hexagons and twelve pentagons (Fig. 1c). The diameter of fullerene C60 is $0.7 \mathrm{~nm}$ [13].

\section{Carbon nanotubes (CNTs)}

Among other carbon-based nanomaterials, CNTs are one of the carbon allotropes with exceptional properties suitable for technical applications. They were discovered in 1991 by the Japanese researcher S. Iijima. Carbon nanotubes are characterized by cylindrical structures with a diameter of several nanometers, consisting of rolled graphene sheets (Fig. 1d). Carbon nanotubes may vary in length, diameter, chirality (symmetry of the rolled graphite sheet) and the number of layers. According to their structure, CNTs may be classified into two main groups: single-walled nanotubes (SWCNTs) and multi-walled nanotubes (MWCNTs). Some researchers additionally isolate double-walled carbon nanotubes (DWCNTs) as a separate class of CNTs. Generally SWCNTs have a diameter around 1-3 nm and a length of a few micrometers. Multi-walled CNTs have a diameter of 5-40 nm and a length around $10 \mu \mathrm{m}$. However, recently synthesis of CNTs with a length of even $550 \mathrm{~mm}$ has been reported [14]. The structure of CNTs leads to exceptional properties with a unique combination of rigidity, strength and elasticity compared with other fibrous materials. For instance, CNTs exhibit considerably higher aspect ratios (length to diameter ratios) than other materials, and larger aspect ratios for SWCNTs as compared with MWCNTs due to their smaller diameter. Additionally, CNTs show high thermal and electrical conductivity compared to other conductive materials. Electrical properties of SWCNTs depend on their chirality or hexagon orientation with respect to the tube axis. Accordingly, SWCNTs are classified into three sub-classes: (i) armchair (electrical conductivity > copper), (ii) zigzag (semiconductive properties) and (iii) chiral (semi-conductive properties) (Fig. 1e). By contrast, MWCNTs consisting of multiple carbon layers, frequently with variable chirality, can exhibit extraordinary mechanical properties instead of outstanding electrical characteristics.

\section{Graphene}

Graphene is a two-dimensional allotropic form of carbon, formed by single layers of carbon atoms (Fig. 1f). In graphene, carbon atoms exhibit $\mathrm{sp}^{2}$-hybridization connected by $\sigma$ - and $\pi$-bonds in a two-dimensional hexagonal crystal lattice with a distance of $0.142 \mathrm{~nm}$ between neighboring atoms of carbon hexagons. Graphene also represents a structural element of some other carbon allotropes, such as graphite, carbon nanotubes and fullerenes.

Theoretical studies on graphene began a long time before the real material samples were obtained. The Canadian theoretical physicist P. R. Wallace first explored the theory of graphene in 1947, while the first graphene samples were described 57 years later (in 2004) by A. Geim (Dutch-British physicist) and K. Novoselov (Russian-British physicist), awarded with a nobel prize in 2010.

Despite the long history of theoretical investigation, the fact that the real material has been obtained only recently, implies that comprehensive studies on the properties of graphene are still ongoing. Graphene has many unique physical properties, such as extremely high mechanical rigidity and a high thermal stability. Also the electric properties of this carbon allotrope are fundamentally different from the properties of three-dimensional materials.

\section{Synthesis of carbon-based nanomaterials} Industrial synthesis of carbon-based nanomaterials Fullerenes Since the discovery of carbon-based nanomaterials, their outstanding properties have been intensively studied and different methods for synthesis have been developed. The basic components for carbon nanomaterial production are carbon vapors. Fullerenes were produced for the first time by W. Krätschmer and D.R. Huffman in 1990 by evaporation of graphite electrodes in a helium atmosphere $[15,16]$. Later, a reactor was modified by establishing an electric arc between two graphite electrodes. The resulting soot condenses on the cold surface of the reactor, and is collected and processed in boiling toluene, benzene, xylene, or other organic solvents. After evaporation of the solvents a black condensate is formed, containing about $10-15 \%$ of C60 and C70 fullerenes, as well as small amounts of higher fullerenes. 
Depending on the synthesis parameters, the ratio between the C60 and C70 fullerenes varies, but typically C60 represents the dominant fraction. The described arcdischarge method belongs to the large family of plasma methods which are most popular and commonly used compared to other techniques [17]. However, the practical use of fullerenes is limited due to high costs and the low productivity of the methods currently available for their synthesis.

Carbon nanotubes Arc discharge, laser ablation and chemical vapor deposition (CVD) are basic methods for CNT synthesis [18]. Currently, one of the most investigated and commonly used techniques for CNT production is CVD [19]. In contrast to two other methods (arc discharge and laser ablation), CVD synthesis requires simpler equipment and milder conditions in terms of temperature and pressure, making it more suitable for the large-scale production of CNTs [20]. CVD synthesis is based on decomposition of hydrocarbons to carbon, and subsequent synthesis of carbon nanostructures on various substrates containing catalysts on which the nanotubes are growing. Metal-based nanoparticles are frequently used as catalysts and their size strongly correlates with the diameter of nanotubes synthesized on it $(0.5-5 \mathrm{~nm}-$ for SWCNTs, $8-100 \mathrm{~nm}-$ for MWCNTs synthesis). Nickel, cobalt or iron nanoparticles are usually acting as catalysts for the synthesis of SWCNTs and MWCNTs.

Reactors for CVD synthesis generally consist of a reaction chamber and tubes filled with inert gas and hydrocarbon (Fig. 2a). Methane is frequently used for SWCNT production, while ethylene or acetylene for MWCNTs. As a simplified process description, the substrate is heated up to $850-1000{ }^{\circ} \mathrm{C}$ in case of SWCNT and up to $550-700{ }^{\circ} \mathrm{C}$ for MWCNT production. Carbon is formed by thermal decomposition of hydrocarbons and dissolves in the metal nanoparticle catalyst. After reaching a certain threshold concentration of carbon, it forms a semifullerene cap, as a starting structure for the growth of a cylindrical shell nanotube, formed by a continuous flow of carbon from the hydrocarbon source to the catalyst particle (Fig. 2b, c). Final removal of the catalysts from the tips of the nanotubes and further purification are still under development and optimization in order to yield CNTs of a higher quality $[21,22]$.

Industrial applications of CNTs and especially of SWCNTs require homogeneous materials with specific properties. However, shifting from well-controlled laboratory conditions to large-scale production frequently results in heterogeneous products, containing impurities of amorphous carbon, carbon fiber, catalyst residuals and other

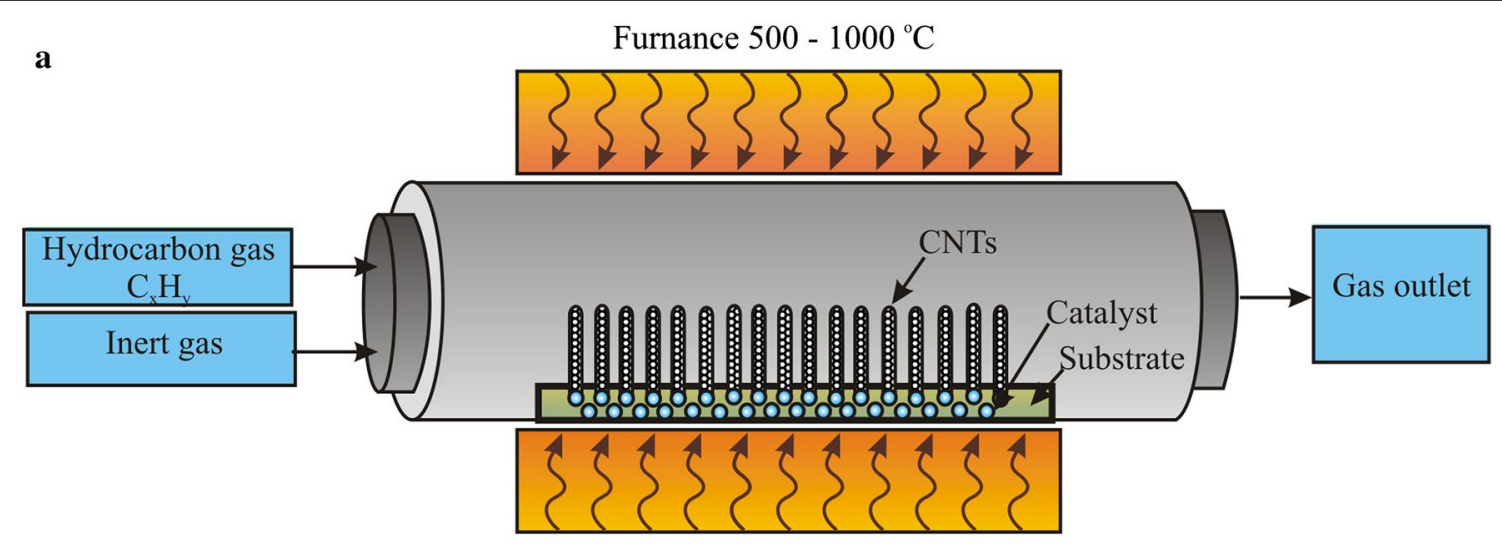

$\mathbf{b}$

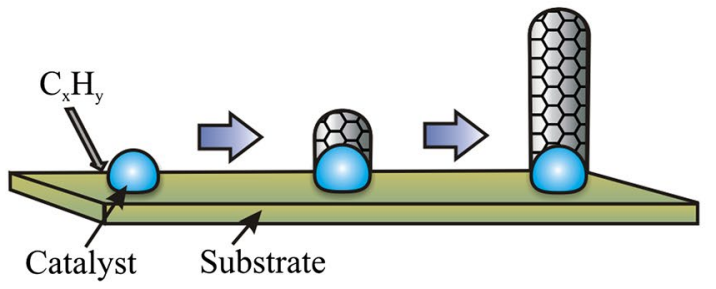

c

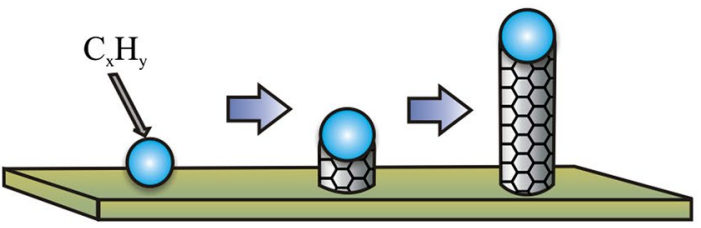

Fig. 2 Schematic representation of chemical vapor deposition (CVD) process. a Simplified scheme of a CVD reactor for CNTs synthesys; b basegrowth model of CNT growth mechanism; c tip-growth model of CNT growth mechanism 
nanoparticles. Therefore, CNT production frequently requires further purification and separation steps, substantially increasing the production costs. One of the major challenges regarding controlled synthesis of SWCNTs is related to difficulties in obtaining small metal-catalyst particles, their equal dispersion on the substrate and prevention of aggregation. For instance, sintering of fine catalysts into larger particles, leads to an increased diameter of SWCNTs or to formation of DWCNTs and MWCNTs.

Chirality, as another structural feature of SWCNTs, also depends on synthesis conditions and the growth mechanism of the nanotubes. Very often, the yielded products represent a mixture of conductive and semiconductive SWCNTs, requiring further extraction steps to obtain SWCNTs with defined chirality for specific applications. Establishing convenient methods for sorting nanotubes according to their characteristics (diameter, chirality) and eliminating various undesired impurities will significantly contribute to the developmental progress towards improved applications. Another important area of research is synthesis of vertically or horizontally aligned CNTs, which have numerous structural advantages as compared to bundles of agglomerated CNTs. Production of MWCNTs seems to be less complicated and expensive. However, the controlled formation of inner and outer diameters or defined numbers of walls are still major challenges.

Graphene Since graphene sheets were first obtained by Gheim and Novoselov, using mechanical splitting of graphite with adhesive tape [23], great progress in graphene research has been made, and meanwhile various methods for graphene production are available [24]. These techniques are based on obtaining nanoscale graphene sheets by splitting or cutting materials, such as graphite or nanotubes [25], using a range of physical or chemical methods. Production of graphene sheets by CVD synthesis or laser ablation methods is also possible. The different methods are able to provide graphene or reduced graphene oxide sheets of different qualities, depending on the requirements of the corresponding applications. Graphene of moderate quality for structural applications can be obtained in large quantities with relatively low production costs. High quality graphene for electronic devices produced in smaller quantities, are usually more expensive. Liquid phase and thermal exfoliation of graphite, CVD synthesis (potentially most cost effective) and synthesis on silicon carbide-are the major methods suitable for mass production of graphene [24].

Chemical functionalization of carbon-based nanoparticles A wide variety of carbon-based nanomaterials can be further expanded by so-called chemical functionalization.
Very often, nanoparticles are functionalized by linking certain molecules to the nanoparticle surface, in order to modify the physical and chemical properties of the particles [26], which in turn greatly expands the field of applications $[26,27]$. One example for functionalization of carbon-based nanoparticles is an oxidation of CNTs. This process comprises an ultrasonic treatment of nanotubes in a mixture of acids, leading to attachment of carboxylic functional groups $(-\mathrm{COOH})$ on the sidewalls of the nanotubes (Fig. 1g). Oxidized CNTs acquire solubility in aqueous solutions, but retain their mechanical and electrical properties. Moreover, carboxylic groups attached to the nanotube surface can serve as sites for further functionalization. There are also examples of functionalized fullerenes and graphene.

\section{Naturally occurring carbon nanomaterials}

Apart from engineered nanomaterials, naturally occurring carbon-based nanoparticles have also been identified $[28,29]$. Velasco-Santos et al. [28] reported the presence of carbon nanotubes in a coal-petroleum mix. For SWCNT synthesis using the CVD method, Su and Chen [30] and Mracek et al. [31] used volcanic lava as a substrate and catalyst, containing particles of metal oxides. The authors speculated that this process may provide evidence for a possible formation of nanotubes under natural conditions when the temperature rises extremely high e.g. during volcano eruptions. Beside carbon nanotubes, there is also evidence for the occurrence of fullerenes in geological materials. Fullerenes have been detected in the natural mineral shungit from Karelia in low concentrations ( $2 \% \mathrm{w} / \mathrm{w})$ [32-35] and also in meteorite samples of cosmic origin [36].

Interestingly, the spherical structure of fullerenes seems to be not only restricted to carbon nanomaterials. Recently, fullerene-like structures have been described in pollen grains of Chinese hibiscus (Hibiscus rosa-sinensis), with putative functions for mechanical stability and adaptive properties important for the pollination process [37].

\section{Potential applications of carbon-based nanomaterials}

The unique physical and chemical properties of carbonbased nanomaterials determine a wide range of options for practical applications, which in turn trigger the increase of their production. The most widespread field of applications has been reported for CNTs. In 2013, the industrial production of CNTs already exceeded several thousand tons [9]. Due to their mechanical properties, namely the high tensile strength, they are incorporated into polymers and other materials in order to create structural and composite materials with advanced properties [38]. For instance, a material obtained by directly 
growing CNTs in a cement matrix had double the compressive strength of the original [39]. Carbon nanotubes allow to producing not only very strong, but at the same time extraordinarily light materials with application fields in the production of wind-turbine blade materials [40, 41] and marine turbines [42], in the automotive industry [43], aviation [44] or in sport equipment [9]. Other areas where carbon nanotubes can be used include various electronic applications $[9,45]$. Fullerenes and their derivatives can be used in medicine [46], including drug and gene delivery [47] or in cosmetics [48-50]. Graphene has numerous applications as well: it can be used in electronics, various biochemical sensors, in solar cells and others summarized in a recently published review by Choi et al. [51]. Beside the examples listed above, carbon-based nanomaterials also have numerous potential applications in the environmental and agricultural sectors, summarized in Fig. 3.

\section{Environmental applications of carbon-based nanomaterials}

Environmental pollution is one of the major global challenges since pollutants of different nature contaminate urban and agricultural areas. In order to improve pollutant remediation strategies for environmental sustainability, there is a need to increase the efficiency of conventional methods or to introduce innovative approaches. In this context, nanotechnology, and especially carbon-based nanomaterials can greatly contribute because they possess an enormous absorption potential due to their high surface area.

Activated carbon (AC) has been widely used as a sorbent for conventional wastewater treatment due to its large surface area and ability to adsorb a broad spectrum of organic and inorganic contaminants. However, AC has slow adsorption kinetics; it is a nonspecific adsorbent and its effectiveness against microorganisms is low. The presence of solids, oil and grease in wastewater often causes pore blockage in AC. Moreover, AC is frequently removed together with the adsorbed pollutants and therefore, needs to be replaced in regular intervals. In this context, utilization of carbon-based nanomaterials has a promising potential to improve wastewater filtration systems with numerous examples in the available literature [52-55]. It has been reported that the adsorption capacity of CNTs towards microcystins (cyanobacterial toxins) [56], lead [57] and copper (III) [58] was even stronger than that of AC. Multi-walled nanotubes have been also used for sorption of antibiotics [59], herbicides [60] or nitrogen and phosphorus in wastewater [61]. On the other hand, fullerenes as well as CNTs exhibit a mobilization potential for various

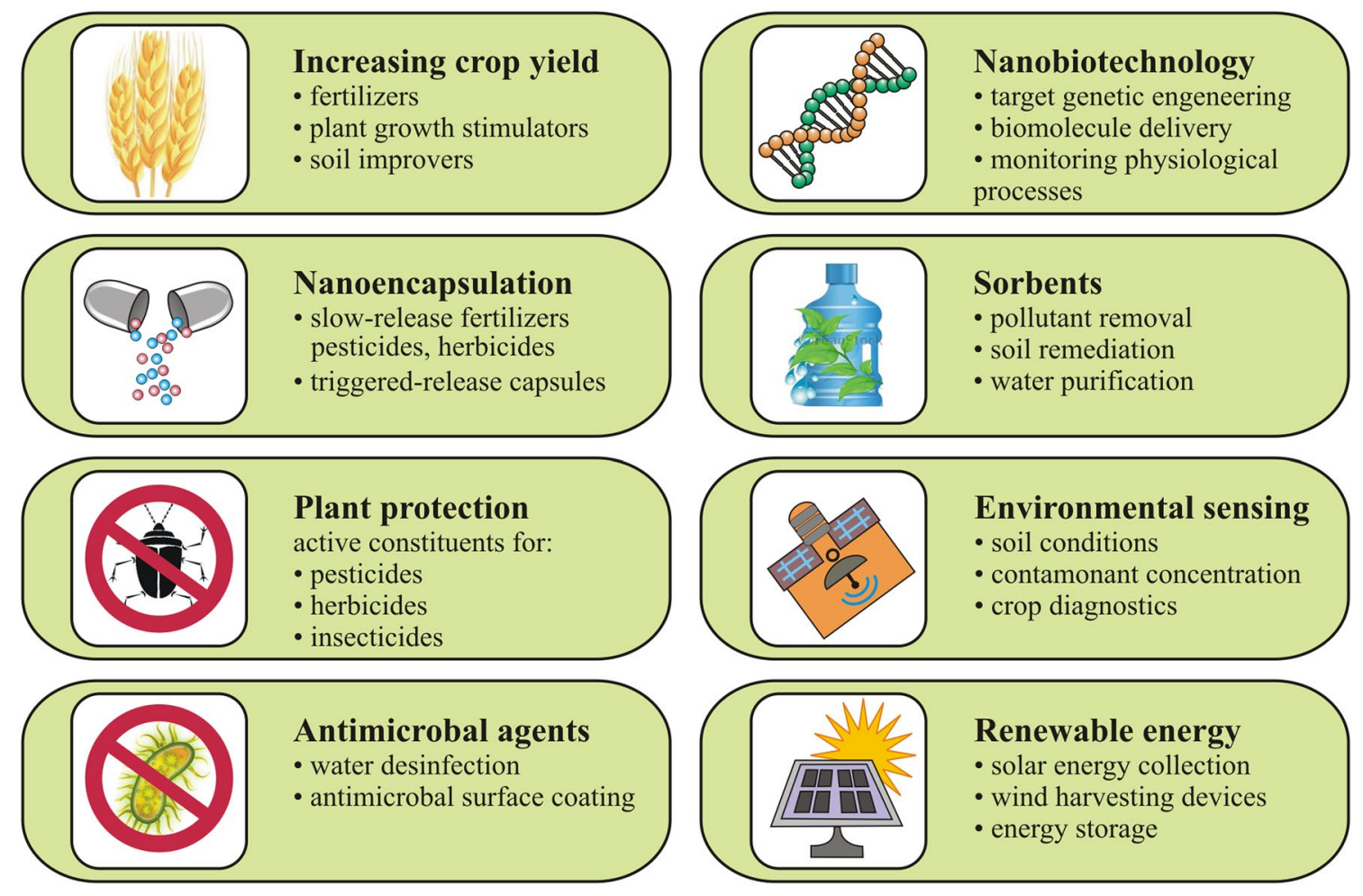

Fig. 3 Potential applications of carbon-based nanomaterials in environmetal and agricultural sectors. See text for details 
organic pollutants [62], such as lindane (agricultural insecticide) [63] and persistent polychlorinated biphenyls [64]. The significant advantages of CNMs comprise their enormous surface area, mechanical and thermal stability, high chemical affinity for aromatic compounds [65], and potential antibacterial properties (described below). Moreover, contaminants can be desorbed from CNMs, and therefore, filters based on CNMs can be recycled [66, 67]. However, challenges related with high costs of CNM production, difficulties in obtaining of CNTs with uniform size and diameter distribution, uncertainties regarding the leaching potential of CNTs, as well as ecological safety and human health issues are still limitations for commercial applications in wastewater clean-up technologies.

Carbon-based nanomaterials also possess antimicrobial properties, although the mode of action is still under investigation. Some studies suggest possible applications of CNTs for disinfection purposes or antimicrobial surface coatings. Particularly silver-(Ag)-coated CNTs hybrid nanoparticles have shown antimicrobial activity [68] and the authors suggest that such materials could find their applications in biomedical devices and antibacterial control systems. Al-Hakami et al. [69] described a method of water disinfection based on interactions of functionalized CNTs with microwaves. According to the authors, CNTs, functionalized with the aliphatic alcohol 1-octadecanol $\left(\mathrm{C}_{18} \mathrm{H}_{38} \mathrm{O}\right)$ had outstanding antimicrobial properties since the long carbon chains contributed to a better absorption of the microwaves by CNTs. Water purification technologies employing CNTs, including water disinfection have been described in the comprehensive reviews of Upadhyayula et al. [70] and Das et al. [71]. Studies on antibacterial and antifungal properties of graphene, CNTs and fullerenes, and their applications in agriculture are summarized in "Antifungal and antibacterial agents" section below.

Additionally, not only removal of pollutants from different environmental compartments, but also monitoring of contamination levels has considerable importance. Carbon-based nanomaterials can be employed for the development of novel, very efficient biochemical sensors for detecting of very low concentrations of chemical compounds in different environments. These sensors also exhibit application potential in agriculture and are discussed in more detail in "Sensing systems and precision agriculture" section.

\section{Agricultural applications of carbon-based nanomaterials} Increasing and optimizing agricultural production on limited areas of arable land sustainably with a minimum negative impact on the environment are major challenges in a future with a continuously increasing world population. Potential contributions of modern nanotechnology in this context comprise [72-74]:

1. Increase of crop productivity by use of plant growth promoters and new fertilizers based on nanomaterials;

2. Application of nanomaterial-based plant protection products [75] including pesticides [76, 77] and herbicides [78];

3. A general reduction of applied agrochemicals using nanoencapsulated plant protection products and slow-release fertilizers;

4. Nanotechnologies for optimization of agricultural practices by introducing precision farming [79].

According to Gogos et al. [75], $40 \%$ of all contributions of nanotechnology to agriculture will be provided by carbon-based nanomaterials acting as additives as well as active components. The majority of such applications are still in the developmental stage and a selection of promising approaches will be presented in this section.

\section{Plant growth stimulators and fertilizers}

A range of studies have reported a positive impact of carbon-based nanomaterials on plant growth (see "Impact of carbon-based nanomaterials on plants" section), stimulating research on nano-carbon containing fertilizers. Selected patents of various nano-fertilizers and soil improvers are listed in Additional file 1: Table S1. The majority of these fertilizers are based on amendments of mineral and organic fertilizers with nano-carbon, which in most cases acts as a fertilizer synergist with the aim of improving plant nutrient availability, reducing nutrient losses and stimulating plant growth.

\section{Nanoencapsulation and smart delivery systems}

Development of smart delivery systems-a promising technique for target delivery of agrochemicals-has numerous potential advantages. Encapsulated agrochemicals exhibit improved stability, and protection from degradation as a perspective to reduce the amount of applied agrochemicals and increase their use efficiency [80]. In this context Sarlak et al. [76] demonstrated that fungicides, encapsulated in MWCNTs functionalized with citric acid, had a higher toxicity against Alternaria alternata fungi compared to the not encapsulated bulk pesticide.

A still common practice of fertilizer application in conventional agriculture is broadcasting or foliar application by spraying. These techniques are often associated with considerable losses of nutrients by leaching or evaporation. So-called slow release or controlled release fertilizers are employed for adaptation of the nutrient supply to the current demand of the plant, avoiding temporal overdoses, 
Table 1 Influence of carbon-based nanomaterials on seed germination

\begin{tabular}{|c|c|c|c|c|c|c|c|}
\hline Plant specie & Type of NPs & Size of NPs & $\begin{array}{l}\text { Concentration } \\
\left(\mathrm{mg} \mathrm{L}^{-1)}\right.\end{array}$ & $\begin{array}{l}\text { Germination } \\
\text { medium }\end{array}$ & $\begin{array}{l}\text { Exposure } \\
\text { duration }\end{array}$ & Effects & Ref \\
\hline Maize & SWCNTS & $\begin{array}{l}\varnothing 1-2 \mathrm{~nm} \\
\mathrm{~L} 30 \mu \mathrm{m}\end{array}$ & 20 & MS medium & $72 \mathrm{~h}$ & No effect on seed germination & [118] \\
\hline $\begin{array}{l}\text { Radish, rape, } \\
\text { ryegrass, lettuce, } \\
\text { maize, cucumber }\end{array}$ & MWCNTS & $\begin{array}{l}\varnothing 10-20 \mathrm{~nm} \\
\mathrm{~L} 1-2 \mu \mathrm{m}\end{array}$ & 2000 & Dl water & 5 days & $\begin{array}{l}\text { No effect on seed germina- } \\
\text { tion }\end{array}$ & [158] \\
\hline Alfalfa, wheat & MWCNTS & $\varnothing 3 \pm 4 \mathrm{~nm}$ & $40-2560$ & Agar medium & 4 days & $\begin{array}{l}\text { No effect on seed germina- } \\
\text { tion }\end{array}$ & [190] \\
\hline Zucchini & MWCNTS & $\begin{array}{l}\varnothing 13-16 \mathrm{~nm} \\
\mathrm{~L} 1-10 \mu \mathrm{m}\end{array}$ & 1000 & $\begin{array}{l}\text { Hoagland } \\
\text { medium }\end{array}$ & 12 days & $\begin{array}{l}\text { No effect on seed germina- } \\
\text { tion }\end{array}$ & [126] \\
\hline Mustard, black lentil & MWCNTS & $\begin{array}{l}\varnothing 110-170 \mathrm{~nm} \\
\mathrm{~L} 5-9 \mu \mathrm{m}\end{array}$ & $10,20,40$ & DI water & 7 days & $\begin{array}{l}\text { No effect on seed germina- } \\
\text { tion }\end{array}$ & [160] \\
\hline Wheat & oMWCNTS & $\begin{array}{l}\varnothing 6-13 \mathrm{~nm} \\
\mathrm{~L} 2.5-0 \mu \mathrm{mm}\end{array}$ & $10,20,40,80,160$ & Dl water & 7 days & $\begin{array}{l}\text { No effect on seed germina- } \\
\text { tion }\end{array}$ & [159] \\
\hline $\begin{array}{l}\text { Wheat, maize, pea- } \\
\text { nut, garlic bulb }\end{array}$ & WSMWCNTS & $\begin{array}{l}\varnothing 10-20 \mathrm{nmL} \\
10-30 \mu \mathrm{m}\end{array}$ & 20,50 & DI water & 5-10 days & Enhanced germination & [191] \\
\hline $\begin{array}{l}\text { Barley, maize, } \\
\text { soybean }\end{array}$ & MWCNTS & na & $50,100,200$ & MS medium & 10 days & Accelerated germination & [128] \\
\hline $\begin{array}{l}\text { Barley, maize, soy- } \\
\text { bean, }\end{array}$ & MWCNTS & na & $25,50,100$ (spray) & Water & 10 days & $\begin{array}{l}\text { At } 25 \mathrm{mg} \mathrm{L}^{-1} \text { no effect, at } \\
100 \mathrm{mg} \mathrm{L}^{-1} \text { increased } \\
\text { germination rate }\end{array}$ & [128] \\
\hline Tomato & MWCNTS & na & $10,20,40$ & MS medium & 20 days & $\begin{array}{l}\text { Increased seed moisture } \\
\text { content, accelerated } \\
\text { germination, improved } \\
\text { germination rate }\end{array}$ & [154] \\
\hline Rice & CNTs & $\begin{array}{l}\varnothing 8 \mathrm{~nm} \\
\mathrm{~L} 30 \mu \mathrm{m}\end{array}$ & $50,100,150$ & MS medium & 6 days & $\begin{array}{l}\text { Enhanced germination speed } \\
\text { and rate }\end{array}$ & [192] \\
\hline Rice & CNTs & na & na & $\begin{array}{l}\text { Basal growth } \\
\text { medium }\end{array}$ & na & $\begin{array}{l}\text { Increased seed water con- } \\
\text { tent, germination rate }\end{array}$ & [156] \\
\hline $\begin{array}{l}\text { Tomato, onion, } \\
\text { turnip, radish }\end{array}$ & CNTs & $\begin{array}{l}\varnothing 8-15 \mathrm{~nm} \\
\mathrm{~L}>10 \mu \mathrm{m}\end{array}$ & 10,20 and 40 & $\begin{array}{l}\text { Ultra-pure } \\
\text { water }\end{array}$ & 12 days & $\begin{array}{l}\text { Improved germination of } \\
\text { tomato and onion }\end{array}$ & [193] \\
\hline Tomato & Graphene & na & 40 & DI water & 11 days & Accelerated germination & [172] \\
\hline Rice & Graphene & na & $5,50,100,200$ & na & 16 days & $\begin{array}{l}\text { Delayed germination with } \\
\text { the increasing of graphene } \\
\text { concentration }\end{array}$ & [173] \\
\hline Wheat & $\begin{array}{l}\text { Graphene, } \mathrm{GO}, \\
\text { graphene ribbon }\end{array}$ & & 200 & Water & 5 days & $\begin{array}{l}\text { Graphene and GO: inhibited } \\
\text { germination, graphene } \\
\text { ribbon: enhanced germina- } \\
\text { tion }\end{array}$ & [174] \\
\hline
\end{tabular}

$\varnothing$ diameter, $L$ length, DI water deionized water, wsMWCNTs water soluble MWCNTs, oMWCNTs oxidized MWCNTs, MS medium Murashige and Skoog medium, GO graphene oxide

extending the time of function, and counteracting losses by leaching. Slow release fertilizers can be encapsulated by graphene oxide films [81]. Even for very soil-mobile nutrients, such as potassium nitrate, encapsulation by graphene oxide considerably prolongs the process of fertilizer release and large-scale production of encapsulates seems to be possible at a relatively low cost [81].

Smart delivery systems of agrochemicals and organic molecules including transport of DNA molecules or oligonucleotides into plant cells are potential applications of nano-biotechnology, based on the ability of carbon nanomaterials to penetrate through cell walls and membranes of plant cells [82]. A recently published study reported a possibility to deliver SWCNTs and ceria nanoparticles into isolated chloroplasts. These nanoparticles, passively penetrating through the chloroplast membrane via diffusion were able to influence photosynthetic activity by supplying electrons into the photosynthetic electron transport chain [83]. Apart from agricultural applications, CNTs are also being investigated as molecular transporters also in animal cells for medical purpose [84-90]. In parallel, much attention is paid to research and development of techniques for directed modifications of CNTs to prevent cytotoxicity. Some of these approaches are summarized in the review by Jain et al. [91]. 


\section{Antifungal and antibacterial agents}

Due to antifungal properties, carbon-based nanomaterials are promising materials for the development of novel fungicides [92]. Among the various carbon nanomaterials including nanotubes, fullerenes and graphene oxide, tested against two plant pathogenic fungi Fusarium graminearum and F. poae, SWCNTs showed the strongest antifungal activity. By contrast, fullerenes and activated carbon used in the assay were largely ineffective. According to Wang et al. [92], an important prerequisite determining the antifungal activity seems to be a tight contact of the nanoparticles with the fungal spores, which induces plasmolysis, associated with reduced water content and growth arrest.

In other studies, anti-microbial activity of graphene oxide (GO) has been attributed to induction of microbial membrane damage, disturbance of the membrane potential [93] and electron transport [94], as well as oxidative stress by increased production of reactive oxygen species (ROS) [95, 96]. Antibacterial properties of graphene oxide were also found to be dependent on the size of the GO sheets: larger GO sheets, wrapping bacterial cells, can effectively isolate bacteria from their environment, and show stronger antibacterial activity as compared to small GO sheets [97]. Also the basal plane of GO sheets seems to play a key role in this mechanism [98] since masking of the basal plane by non-covalent protein adsorption with bovine serum albumin resulted in loss of antibacterial activity [98]. Accordingly, sticking the layers of GO sheets closely together [99] to avoid the interactions of bacteria with the sharp edges of single GO sheets, while keeping contact of the bacteria with the basal plane, retained the antimicrobial activity. These findings underline the importance of the basal plane as a central structural element mediating antibacterial properties of GO.

The CNMs with antifungal and antimicrobial properties described above received considerable attention due to potential applications as novel fungicides and disinfection agents suitable for agricultural purposes (e.g. in plant protection). However, due to the largely unknown behavior of CNMs in complex environmental matrices, it is quite difficult to predict to what extent the described in vitro properties will be manifested when the CNMs or $\mathrm{CNM}$-containing products are released into the environment. This requires much more detailed investigations of the antifungal and antibacterial properties of CNMs, considering a wider range of crops and pathogens to be investigated under real field conditions [92]. On the other hand, for environmental risk assessment, the potential impact of CNMs on non-target organisms also requires comprehensive evaluation before commercialization of novel agrochemicals.

\section{Sensing systems and precision agriculture}

Carbon-based nanomaterials with novel chemical, physical and mechanical properties are employed to develop highly sensitive sensors and diagnostic devices for numerous agricultural and environmental applications. Nanosensors exhibit numerous operating principles [100] but a common mode of action is conversion of physicochemical properties into signals. The high sensitivity of these devices is determined by the nanoscale size of the sensing elements, such as carbon nanotubes. Therefore, a few molecules are frequently sufficient to influence the electrical properties (chemical to electrical transduction) of the nanoparticles. Moreover, the great surface area of carbon-based nanomaterials provides large spaces for interactions with the sensed molecules.

Development of novel technologies based on nanomaterials which can be successfully used for easy, rapid and highly sensitive chemical analysis, is documented in numerous studies. A graphene-based sensor for the detection of cadmium contaminations in water, which works effectively at concentration levels of $0.25 \mu \mathrm{g} \mathrm{L} \mathrm{L}^{-1}$ has been described by Wu et al. [101]. A highly sensitive sensor for the determination of nickel, not only in environmental samples but also in food, is based on modified nanotubes and has a detection limit of $4.9 \mathrm{ng} \mathrm{L^{-1 }}$ [102]. CNT-based gas sensors for ammonia detection can be used for trace gas measurements [103]. Sensors to detect pesticides, herbicides and their metabolites in environmental samples have been developed based on modified MWCNTs [104, 105] or on GO [106]. Moreover, nanosensors have been employed for monitoring soil moisture [107].

Nanosensor-based monitoring systems for crop health have also been described. In this context, CNT sensors were successfully used for in vivo monitoring of ROS formation in plant tissues as stress indicators [108]. An electronic device for real-time sensing of toxic gases based on CNTs, which could be placed onto insects or plants [109] can be applied in remote sensing systems for plant diseases. Covering a field site with multiple sensors can provide a full picture of the spatial distribution of disease severity at a field scale and allows the detection of hot spots, requiring a special treatment, as a significant contribution to reducing the input of agrochemicals.

However, currently the majority of nanosensors are still in the product development stage and large-scale production has not yet been established due to a number of restrictions. First of all, on the way from the lab to the market scale, long-term testing is required for calibration and validation of the developed devices [110]. Currently, only a limited number of studies reported measurements of real samples under natural conditions [100]. Challenges related with up-scaling production techniques and 
the high costs of the materials and equipment required for the production of nanosensors have been claimed by various authors [111, 112]. Major challenges still remain around the issues of safety, health aspects and risk assessment, requiring an entire life cycle analysis of a product [110]. However, despite the listed issues, several authors are expecting intensive commercialization of nanosensor technologies [113] in the near future, also confirmed by recently issued market forecasts $[114,115]$.

\section{Impact of carbon-based nanomaterials on plants}

Due to the rapid expansion of nanotechnology and the production of engineered nanomaterials, it is essential to understand how nanoparticles interact with living organisms for bio-safety reasons. In the case of nanomaterial-plant interactions, knowledge gained in this direction is not only important in terms of an ecological risk assessment but may also contribute to the development of nanotechnological applications in agriculture towards improved crop yields and reduced input of agrochemicals. Phytotoxicology of engineered nanomaterials is a comparatively new field of research, which according to Nowack and Bucheli [116] did not exist before 2007. Accordingly, the potential toxicity of nanoparticles on plants has not yet been widely investigated, and the reported results are frequently descriptive and contradictory with very limited information on the underlying modes of action [117]. Physiological processes potentially affected by interactions with nanomaterials comprise alterations of gene expression [118, 119], DNA damage $[120,121]$ and increased formation of ROS $[122,123]$. A high variability of responses can be observed between different plant species $[124,125]$, various stages of plant ontogenesis [126] and different varieties [127, 128]. The impacts of carbon-based nanomaterials on seed germination and plant development of different plant species are compiled in Tables 1 and 2, while penetration of carbon nanoparticles into plant tissues is summarized in Fig. 4.

The high variability of nanomaterials in terms of chemical composition, size and shape, surface structure, solubility, aggregation and application modes are also factors most likely contributing to the heterogeneity of plant responses reported in the literature [129, 130]. Knowledge of the special structural features of nanomaterials determining the adverse effects on living organisms is a pre-requisite for the so called "safe-by-design" approach for a directed design of nanomaterials without negative environmental side effects [131-133].

\section{Impact of fullerenes on plants}

Germination Only a limited number of studies report effects of fullerenes or their derivatives on seed germination. For instance, fullerenes applied in aqueous suspensions $\left(10-500 \mathrm{mg} \mathrm{L}^{-1}\right)$ or by soil incorporation (1000 mg kg-1) did not affect seed germination of wheat (Triticum aestivum), rice (Oryza sativa), cucumber (Cucumis sativus) and green gram (Vigna radiata) [134]. The authors explained the absence of fullerene effects on seed germination as a consequence of selective seed coat permeability. Similarly, Liu et al. [135] reported that fullerene malonic acid derivative (FMAD, $\left.\mathrm{C}_{70}\left(\mathrm{C}(\mathrm{COOH})_{2}\right)_{4-8}\right)$ did not affected the germination of Arabidopsis (Arabidopsis thaliana) seeds most likely due to protective effects of seed coat.

Plant growth and development The majority of studies focusing on the effects of fullerenes on terrestrial and aquatic plants, report negative or no effects of fullerene C60 on plant growth and development. Tao et al. [136] found inhibition of photosynthesis and $\mathrm{Mg}$ uptake of phytoplankton exposed to fullerenes C60. Similarly, fullerenes inhibited growth and chlorophyll accumulation in duckweed (Lemna gibba) [137].

In a study of terrestrial plants with fullerene soil amendments used for immobilization of pesticide residues, reduced biomass accumulation was reported at higher fullerene concentrations (500-5000 $\mathrm{mg} \mathrm{kg}^{-1}$ soil): up to $40 \%$ reduction for soybean (Glycine max), $44 \%$ for maize (Zea mays) and $10 \%$ for tomato (Solanum lycopersicum) [138], while inhibition of root growth was detected in pumpkin (Cucurbita pepo) [139].

Several studies have demonstrated a potential of fullerenes to increase accumulation of organic contaminants in plants. Accordingly, in cottonwood (Populus deltoides) cuttings cultivated in hydroponics, accumulation of industrial solvent trichloroethylene added to the growth medium was increased by $80 \%$ in the presence of fullerene C60 (15 $\left.\mathrm{mg} \mathrm{L}^{-1}\right)$ [140]. The authors speculated that a fullerene-trichloroethylene complex, formed in the nutrient solution was taken up by the plants. In another study [141] carried out in a vermiculite substrate, fullerene C60 (40 mg pot $\left.{ }^{-1}\right)$ increased the total plant content of the DDT metabolite dichlorodiphenyldichloroethylene (DDE) in zucchini (C. pepo), soybean (G. max) and tomato (S. lycopersicum) by approximately 30,45 and $62 \%$, respectively. Although fullerenes C60 were detected mainly in the root tissue and at the root surface, a conjugated uptake of C60 together with the contaminant was postulated by the authors. Analyses of plant tissues revealed no membrane disruptions, suggesting that the contaminants did not enter the plant simply via damaged tissues. Genotypic differences in the uptake rates of DTT metabolites in the presence of fullerene C60 have been reported in plants grown on a vermiculite-soil mixture [138] with inhibitory effects recorded for maize (Z. mays) and tomato (S. lycopersicum) but stimulation in soybean (G. max) and zucchini (C. pepo). Interestingly, in a study 


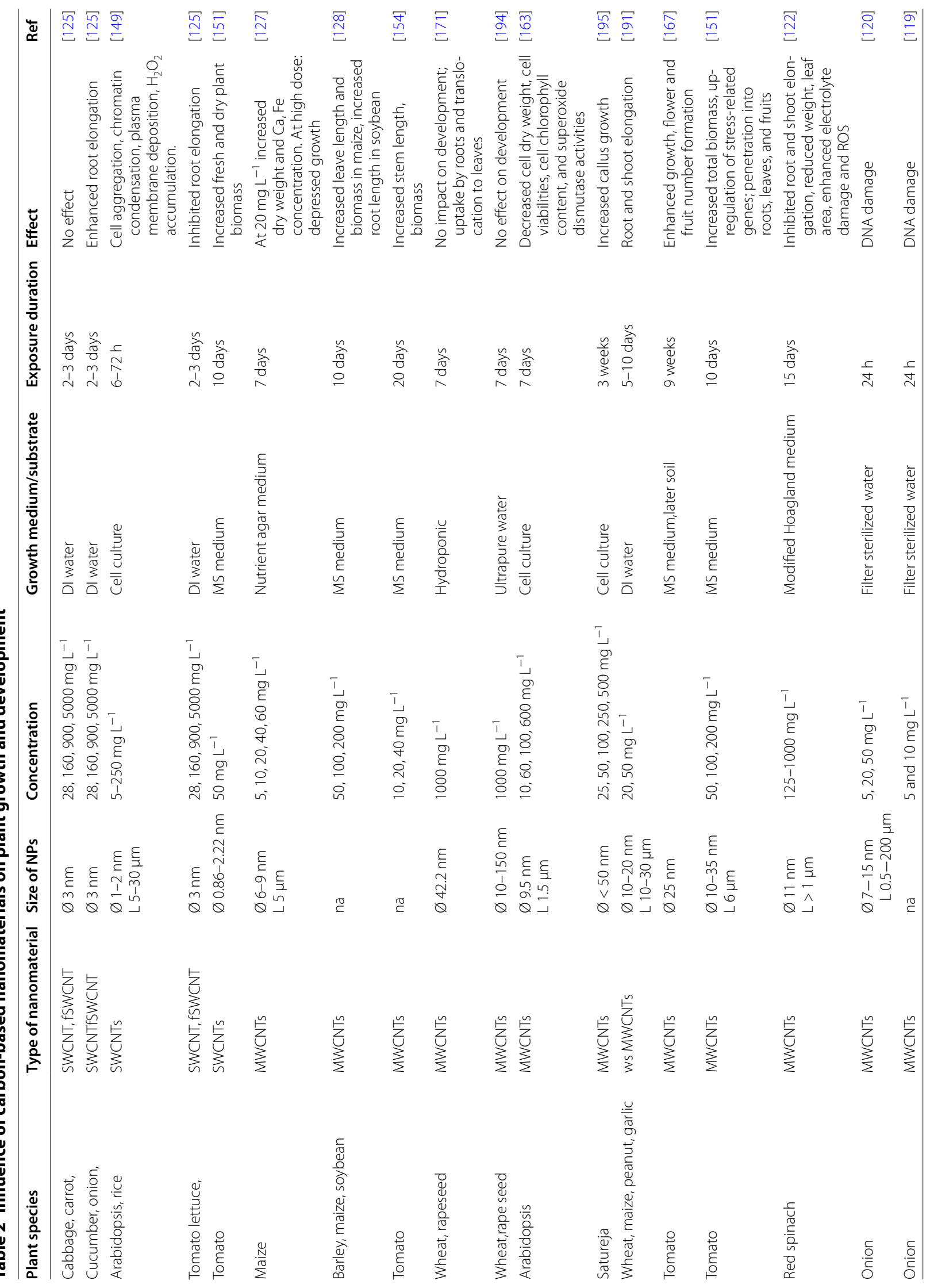




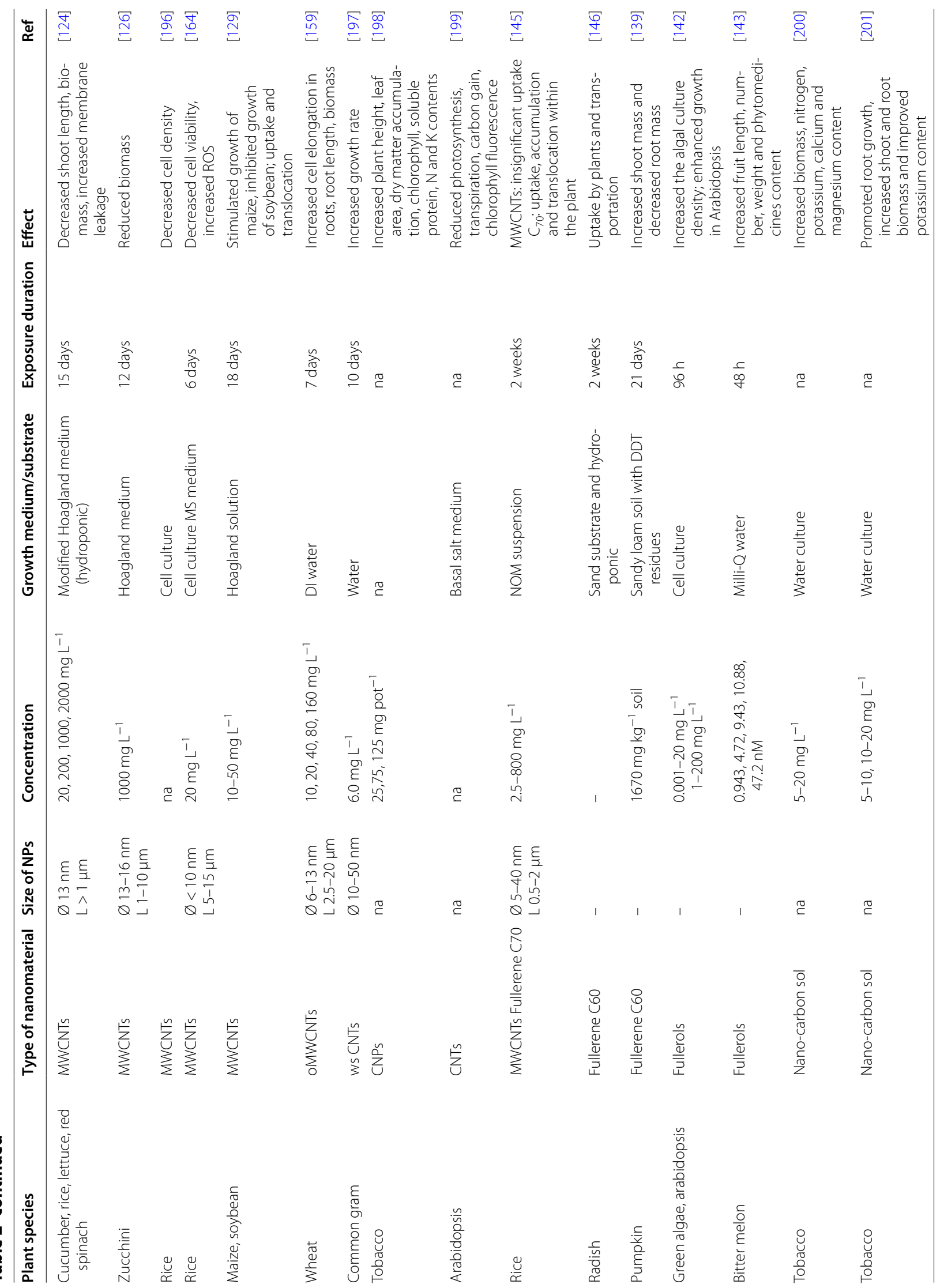




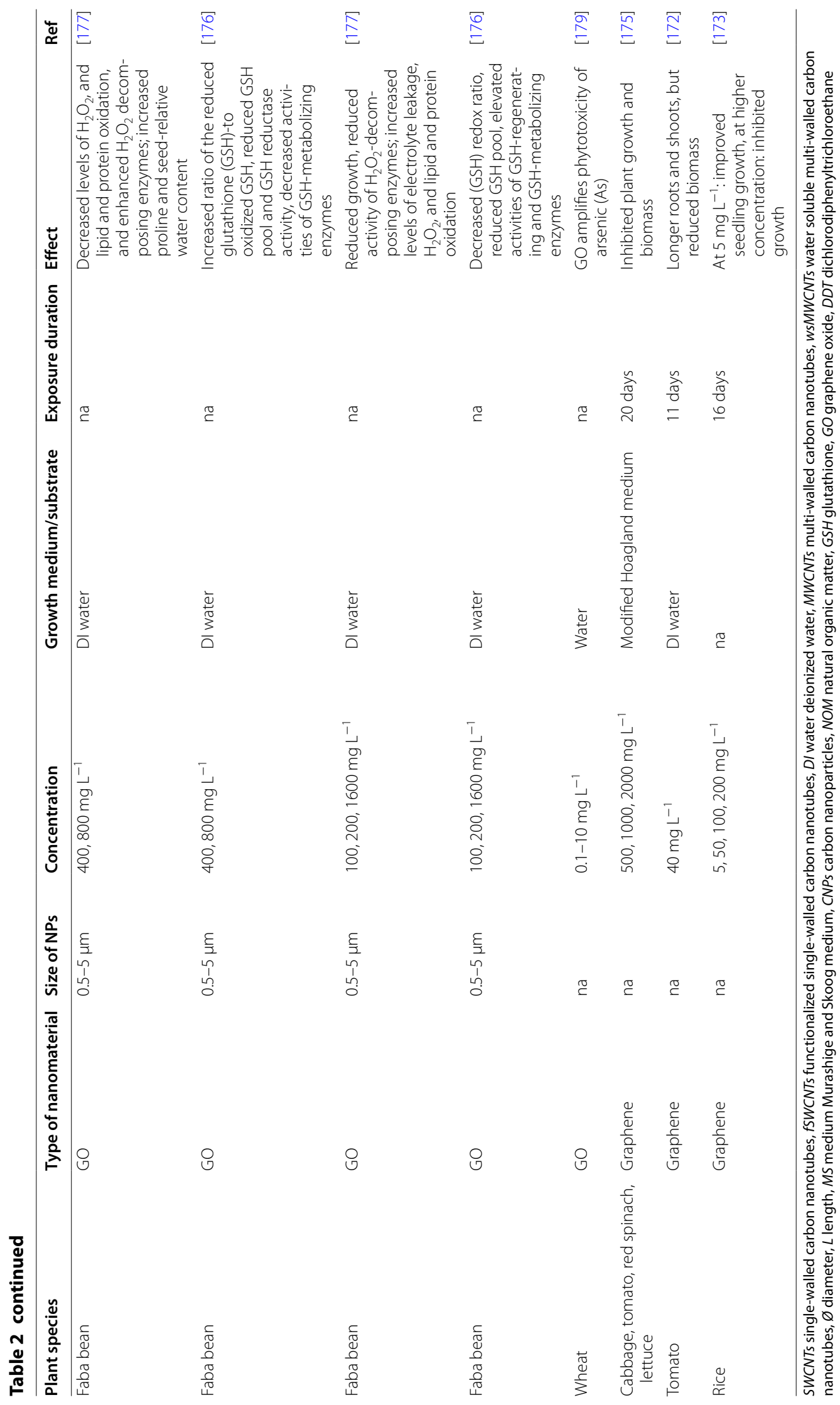




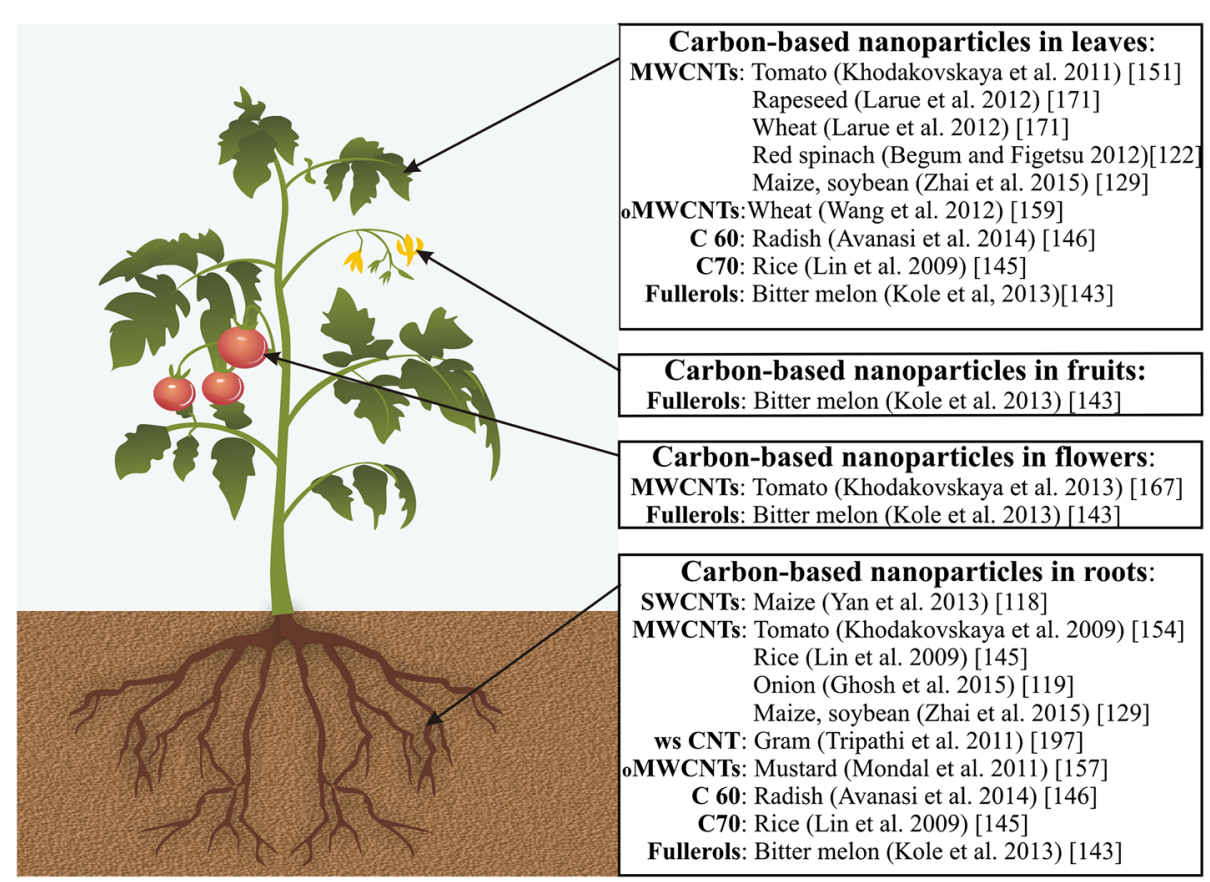

Fig. 4 List of plant species in which carbon-based nanoparticles were detected in different plant organs

conducted on a loamy field soil, containing naturally aged DDE residues, no impact of fullerene C60 amendments on contaminant uptake by pumpkin (C. pepo) was detectable [139]. These findings suggest that plant availability of fullerenes and/or organic contaminants depends not only on substrate properties, but also on differences between plant species.

By contrast, fullerols, as $\mathrm{OH}$-functionalized fullerenes, frequently exerted positive effects on plant growth, such as stimulation of cell divisions in green algae cultures of Pseudokirchneriella subcapitata and of hypocotyl growth in Arabidopsis (A. thaliana) [142]. Fullerol seed dressings even increased fruit number, fruit size and final yield by up to $128 \%$ in bitter melon (Momordica charantia), and are also associated with a higher content of bioactive compounds in fruits, such as cucurbitacin-B, lycopene, charantin and inulin [143]. These findings demonstrate perspectives of hydroxyfullerenes to improve crop yields and product quality. However, further investigations on potential food chain contaminations are still necessary, since fullerol residues have been detected in various plant organs including fruits. The exact mechanism behind plant-growth promotion induced by hydroxyfullerenes is not yet clear, but may be at least partially explained by antioxidant properties [144] connected with the ability of hydroxyfullerenes to accept up to six electrons and distribute them among the aromatic rings, thereby acting as "radical sponges".
However, not all functionalized fullerenes exhibit stimulatory effects on plant growth. As an example Liu et al. [135] reported that a water-soluble fullerene-malonic acid derivative (FMAD), $\mathrm{C}_{70}\left(\mathrm{C}(\mathrm{COOH})_{2}\right)_{4-8}$ added to the growth medium, induced dose-dependent inhibition of root elongation by up to $60 \%$ and deformation of root tips in Arabidopsis (A. thaliana), associated with a disruption of auxin transport in the root tips, aberrations of cell divisions in the root meristematic zone and reduction of intracellular ROS. Growth-inhibitory effects of carboxyfullerenes $\left(\mathrm{C}_{70}\left(\mathrm{C}(\mathrm{COOH})_{2}\right)_{2-4}\right)$ have been similarly reported in tobacco ( $N$. tobacum) cell cultures, connected with cell wall deformations and co-induction of oxidative stress [123]. These findings demonstrate that the type of functionalisation is an important determinant for the effects of nanomaterials on plants.

Uptake of fullerenes and fullerols Lin et al. [145] reported that rice seedlings (O. sativa) grown in hydroponic culture exhibit root uptake of fullerene C70 and translocation to shoots and leaves. The accumulation of C70 was observed in vascular tissues, in surrounding cells and intercellular spaces. Similar to hydroxyfullerenes described above, uptake of fullerenes added to a vermiculite growth substrate was found in root systems of soybean (G. max), tomato (S. lycopersicum) and in both the roots and shoots of zucchini (C. pepo) $[141,146]$. Fullerene C60 accumulated mainly in the root tissue, but smaller quantities were 
detected also in leaves and stems [146]. Uptake of fullerene ${ }^{14} \mathrm{C} 60$ was also reported for radish (Raphanus sativus), grown for 2 weeks in a sand substrate and hydroponic culture, while a rock wool substrate limited the availability of C60 for plant uptake [146]. Although the principal capacity of plant roots to take up fullerenes has been repeatedly demonstrated, unfortunately more detailed studies on plant availability and root uptake under real soil conditions are still lacking $[138,139]$.

\section{Impact of carbon nanotubes on plants}

Compared with fullerenes, many more studies on plant interactions with the various types of carbon nanotubes are available, describing effects on seed germination, early plant growth, cell culture, gene expression and various physiological processes. Concerning toxicity aspects, due to smaller size, SWCNTs seem to be more toxic than MWCNTs, and toxicity is further increased by functionalization of nanotubes [125]. Since CNTs exhibit great tensile strength, mechanical damage of tissues may be induced by piercing effects.

\section{Impact of SWCNTs on plants}

Germination A few studies report effects of SWCNTs on germination rate. Stimulation of seed germination in response to SWCNTs treatments $\left(10-40 \mathrm{mg} \mathrm{L}^{-1}\right)$, potentially induced by perforation of the seed coat, has been reported for salvia (Salvia macrosiphon), pepper (Capsicum annuum), and tall fescue (Festuca arundinacea) [147]. Among the tested treatments, the highest germination rates were obtained by applying moderate SWCNT concentrations: e.g.10 mg L ${ }^{-1}$ SWCNTs for pepper $(C$. annuum) and $30 \mathrm{mg} \mathrm{L}^{-1}$ of for salvia (S. macrosiphon) and tall fescue (F. arundinacea). However, a similar concentration of SWCNTs $\left(20 \mathrm{mg} \mathrm{L}^{-1}\right)$ did not affect the germination of maize ( $Z$. mays) seeds [118].

Plant cell culture For SWCNTs added to the growth media of plant cell cultures, positive as well as negative effects have been observed, depending on the applied dosage. In Arabidopsis (A. thaliana) mesophyll cells, low concentrations of SWCNTs $\left(10-50 \mathrm{mg} \mathrm{L}^{-1}\right)$ exerted stimulatory effects on cell growth, while higher concentrations $\left(100 \mathrm{mg} \mathrm{L}^{-1}\right)$ induced the generation of ROS and toxic effects, associated with necrosis and apoptosis [148]. Similar dose-dependent effects including ROS accumulation and programmed cell death (at $25 \mathrm{mg} \mathrm{L}^{-1}$ ) have been reported for cell cultures of Arabidopsis $(A$. thaliana) and rice (O. sativa), potentially linked with the small particle size of SWCNTs, since particles of activated carbon did not cause similar damage. [149]. It has been speculated that SWCNTs might penetrate cell walls and cell membranes.
Plant growth and development Effects of SWCNTs have been reported mainly for young seedlings grown in aqueous suspensions or various culture media amended with SWCNTs. Stimulatory effects on early seedling growth have been detected for a range of plant species including fig plants (Ficus carica) [150] maize (Zea mays) [118] and tomato (S. lycopersicum) seedlings [151]. A dosedependent effect of SWCNTs was reported for salvia $(S$. macrosiphon), pepper (C. annuum) and tall fescue ( $F$. arundinacea) [147], where $10-30 \mathrm{mg} \mathrm{L}^{-1}$ of SWCNTs increased the formation of seedling biomass, while at $40 \mathrm{mg} \mathrm{L}^{-1}$ SWCNTs exerted negative effects on seedling development. A similar response has been reported for blackberry (Rubus adenotrichos) grown in vitro in a culture medium supplemented with functionalized carboxySWCNTs (SWCNTs-COOH) [152].

However, contradicting effects were observed for short-term applications ( 24 and $48 \mathrm{~h}$ ) of SWCNTs functionalized with poly-3-aminobenzenesulfonic acid and non-functionalized SWCNTs in six important crops [cabbage (Brassica oleracea), carrot (Daucus carota), cucumber (C. sativus), lettuce (Lactuca sativa), onion (Allium cepa), and tomato (Solanum lycopersicum)]. Non-functionalized nanotubes inhibited root elongation in tomato (S. lycopersicum) but exerted stimulatory effects on cucumber (C. sativus) and onion (A. cepa). Root elongation in lettuce ( $L$. sativa) was inhibited by functionalized nanotubes, while cabbage (B. oleracea) and carrot (D. carota) were not affected at all [125]. The authors speculated that the variability of the responses may be related (i) with genotypic differences of the test plants and (ii) with differences in seed size, since smallseeded species, such as lettuce ( $L$. sativa), onion ( $A$. cepa), and tomato (S. lycopersicum) appeared to be more sensitive compared with large-seeded species with a lower surface to volume ratio providing a lower surface area for interactions with SWCNTs.

A limited number of studies linked the effects of plant exposure to SWCNTs on morphological traits with modifications at the molecular level. In maize ( $Z$. mays) grown on Murashige and Skoog medium amended $20 \mathrm{mg} \mathrm{L}^{-1}$ SWCNTs, increased formation of seminal roots was associated with increased expression of the respective genes (SLR1, RTCS), while inhibition of root hair growth was reflected by down regulation of root hair-related genes (RTH1, RTH3). Moreover, similar to plants exposed to stress conditions, SWCNTs could increase histone deacetylation [118], most likely as a response towards SWCNT accumulation in the root cortex.

Uptake of SWCNTS The process of SWCNT penetration into plant cells has been first described in plant cell cultures. Liu et al. [82] reported intracellular penetration 
of water-soluble SWCNTs with a length $<500 \mathrm{~nm}$ in cell cultures of tobacco (N. tobacum). The nanotubes showed the ability to penetrate both the hard cell wall, and the cell membrane, mediated most probably by means of fluidic-phase endocytosis, since nanotube penetration was minimal in presence of endocytosis inhibitors. Temperature did not affect SWCNT internalization into $A$. thaliana mesophyll cells and therefore, the authors proposed a non-energy dependent endocytosis pathway [148]. Later, Shen et al. [149] reported the formation of endocytosis-like structures in the membranes of $A$. thaliana leaf cells in response to SWCNT $(5-30 \mu \mathrm{m})$ treatments. Successful intracellular penetration was shown for functionalized magnetic SWCNTs into canola (B. napus) and carrot (D. carota) cells driven by external magnetic forces. This behavior may reflect the potential of SWCNTs for development delivery carriers for biomolecules [153].

However, less evidence is available for SWCNT uptake by intact plants. In a study by Cañas et al. [125], none of the functionalized and non-functionalized SWCNTs supplied with the growth medium were found in the root tissues of young seedlings (2-3 days) of six plant species, and SWCNTs were mainly sticking to the external root surface. Accordingly, also in maize (Z. mays) the occurrence of SWCNTs was restricted to the root surface and the intercellular spaces of the root cortex [118]. In studies with cell cultures, it has been demonstrated that events of nanotube penetration occur more frequently with high concentrations of SWCNTs rarely present in experiments with whole plants.

\section{Impact of MWCNTs on plants}

Germination In contrast to SWCNTs, stimulatory effects of MWCNTs have been reported for a wider range of different crops. Improved germination rates were described for tomato (S. lycopersicum) (already registered as a patent) $[154,155]$ and rice (O. sativa) [156], while germination speed was accelerated in barley (Hordeum vulgare), soybean (G. max), maize (Z. mays) $[128,157]$ and mustard seeds (B. juncea) [157]. One of the most frequently encountered theories to explain beneficial effects on germination is associated with improved water uptake, demonstrated for tomato (S. lycopersicum) [154], rice $(O$. sativa) [156], and mustard (B. juncea) [157]. Accelerated water flow into the seeds has been related with the ability of CNTs to perforate the seed coat [154]. Later, a concentration-dependent effect of MWCNTs on the expression of aquaporin genes has been reported for germinating seeds of soybean (G. max), barley (H. vulgare) and maize (Z. mays) [128]. Due to a central role of aquaporins in germination, it has been speculated that the beneficial effects of MWCNTs on seed water uptake and germination may be mediated by the described aquaporin effect. However, this assumption is still speculative since additionally to water uptake, aquaporins are involved in many physiological processes including stress responses also induced by CNTs and therefore, more detailed investigation of the involved aquaporin genes is necessary.

Apart from positive effects of MWCNTs on germination, there are also numerous reports claiming the absence of any MWCNT effect in a wide range of different plant species, including radish ( $R$. sativus), rape (B. napus), ryegrass (Lolium perenne), lettuce (L. sativa), maize ( $Z$. mays), cucumber (C. sativus) [158], wheat (T. aestivum) [159], mustard (B. juncea), black lentil (P. mungo), and zucchini (C. pepo) [160]. On the one hand, this discrepancy may be attributed to genotypic differences or variability in seed lot quality of the tested seed material but it may also be the test conditions. Interestingly, it has been shown that different techniques of MWCNT application, such as dispersal in agar medium or spraying onto the seed surface did not change the beneficial effects on the germination of barley ( $H$. vulgare), soybean (G. max) and maize (Z. mays) [128]. However, the chemical composition of the growth media used for the germination tests may play an important role. These media can contain simply distilled water $[158,159]$, but also agar with and without supplementation of mineral nutrients [127] or even complete media used for plant tissue cultures, such as Murashige-Skoog medium [128, 154], supplemented with minerals, amino acids, vitamins and hormones as bioactive compounds [161]. Moreover, even contaminations of CNTs with catalytic impurities, such as $\mathrm{Fe}$ and $\mathrm{Al}_{2} \mathrm{O}_{3}$ can exert a stimulatory effects on seed germination [162].

Plant cell culture Investigations of the influence of MWCNTs on suspension cells of $A$. thaliana showed toxic effects of MWCNTs (10-600 $\left.\mathrm{mg} \mathrm{L}^{-1}\right)$ [163], reflected by inhibited cell growth and cell viability, decreased chlorophyll content and superoxide dismutase (SOD) activity. Comparing two types of MWCNTs, forming larger and smaller agglomerates, revealed higher toxicity of the smaller particles, confirming again that the size of nanoparticles is an important factor determining their toxicity (see "Impact of SWCNTs on plants" section). Investigations of MWCNT effects on rice suspension (O. sativa) cultures revealed increased ROS formation, associated with reduced cell viability, mitigated by the application of ascorbic acid as an antioxidant [164], demonstrating once more that oxidative stress is another important determinant of CNT toxicity. Due to the similar size of CNTs and many pathogens, it has been speculated that CNTs are able to induce a pathogen-like hypersensitive response, associated with an oxidative burst, as a defense 
reaction of plants in response to various kinds of pathogen attacks.

However, positive effects of MWCNTs on plant cell cultures have also been reported. In tobacco ( $N$. tabacum) cells [165] MWCNTs at a dosage of $100 \mathrm{mg} \mathrm{L}^{-1}$ stimulated biomass accumulation, associated with an upregulated expression of cell cycle genes (after $6 \mathrm{~h}$ ), cell growth (after 4 days) and water transport (from $24 \mathrm{~h}$ to 4 days), while during the rest of the exposure time the gene expression did not differ from cells grown in control (MS medium).

Independent of positive or negative plant responses to MWCNT treatments, the direct cell contact of individual or agglomerated CNTs seems to be a prerequisite for the induction of any effects, with differences in plant sensitivity or different physical parameters of CNTs (diameter, length, degree of aggregation) as determinants for the variable expression of plant responses.

Plant growth and development During seedling development and early growth, positive effects of MWCNTs on root and shoot elongation have been reported for a range of plant species, such as tomato (S. lycopersicum) [151, 154, 166], wheat (Triticum aestivum) [159], soybean (G. max), maize ( $Z$. mays) [128], mustard (B. juncea), and black lentil (P. mungo) [160]. A high degree of MWCNT dispersion in the growth medium resulted in more intense stimulation of plant growth as compared to variants containing larger agglomerates of the same MWCNTs [166], suggesting that a uniform and widely distributed contact of smaller MWCNTs with the plant tissues may be a prerequisite for stimulatory effects on plant growth. In many studies the expression of effects was concentrationdependent (see "Impact of SWCNTs on plants" section), with beneficial effects at lower levels of MWCNT application and inhibition at higher concentrations $[127,160]$. As already described for cell culture experiments (see above and "Impact of SWCNTs on plants" section), induction of oxidative stress, associated with ROS formation, membrane damage, electrolyte leakage, mitochondrial dysfunctions, DNA aberration and cell death, has been characterized as determinant for MWCNT toxicity. This was also noted during seedling development and early growth of red spinach (A. tricolor), rice (O. sativa), lettuce (L. sativa) and cucumber (C. sativus) [119, 122, 124] and again small seeds were most sensitive (see also "Impact of SWCNTs on plants" section).

The majority of studies focused on MWCNTs effects on plant growth and development have used hydroponics or agar media as growth substrates, while soil culture has been employed very rarely. Apart from studies on germination and early growth, MWCNT effects have also been investigated in the reproductive stage of plant development. Khodakovskaya et al. [167] reported a doubling of flower setting and yield in tomato (S. lycopersicum), grown in soil with MWCNT amendments, which was not detectable in control soils simply treated with activated charcoal. On the other hand, De La TorreRoche et al. [138] found no indications for effects of MWCNT soil amendments in zucchini (C. pepo) and tomato (S. lycopersicum). This is most likely due to limited mobility of MWCNTs in soil [168] related with a low probability of CNT contact with plant tissues.

Alteration of morphological traits in plants treated with MWCNTs is often associated with changes in gene expression and also with damage of DNA and chromatin structures. Ghosh et al. [119] reported DNA damage, micronucleus formation and chromosome aberration in onion roots $(A$. cepa) in response to MWCNT treatments. In a study with tomato roots (S. lycopersicum) [151], application of MWCNTs to the growth medium triggered overexpression of various biotic stress-related genes, such as subtilisin-like endoprotease, meloidogyneinduced giant cell protein, threonine deaminase, and this was also observed after SWCNT treatments in maize ( $Z$. mays) seedlings [118]. Similarly, the increased expression of aquaporins (water channel proteins) reported for seedlings of tomato (S. lycopersicum) [151, 166], soybean (G. max.), maize (Z. mays), and barley (H. vulgare) with MWCNTs seed treatments may reflect a common stress response [128]. In tomato seedlings (S. lycopersicum), up-regulation of aquaporin gene expression was triggered by highly dispersed MWCNTs with different functional groups attached to the surface, while MWCNTs in the form of large aggregates remained ineffective [166]. Taken together the findings suggest that CNTs are acting as stress factors with the ability to induce plant defense responses and hormesis effects, or toxicities depending on the intensity of the stimulus.

Uptake of MWCNTs Despite the fact, that the diameter and length of MWCNTs are frequently greater than the size of fullerenes and SWCNTs, plant uptake and internal translocation has been reported also for MWCNTs. The majority of such studies have been carried out in hydroponics or agar-like growth media. Multiwalled nanotubes can penetrate not only cells of developing seedlings, but even rigid seed coats by perforation and creation of new pores [154]. For instance, MWCNTs with a diameter range of $15-40 \mathrm{~nm}$ were detected in germinating seeds of barley (H. vulgare), soybean (G. max) and maize ( $Z$. mays) [128]. Once nanotubes have passed the seed coat, contact with the radicle and other seedling organs is possible. Accordingly, small diameter MWCNTs $(<13 \mathrm{~nm})$, present in the germination medium, could penetrate cell walls and were later detected in the roots of wheat ( $T$. 
aestivum) [159] and red spinach (A. tricolor) seedlings [122]. Wild and Jones [169] demonstrated that MWCNTs with a diameter of 110-170 nm could pierce the epidermal cell wall and thus penetrate up to $4 \mu \mathrm{m}$ into the cytoplasm of wheat (T. aestvcum) root hairs. MWCNTs taken up by plant roots were even detected in the xylem and in phloem cells [129]. A root to shoot translocation of MWCNTs is most probably driven by transpiration [170] as demonstrated for wheat (T. aestivum) and rapeseed (B. napus) [171]. In soil-grown tomato plants MWCNTs have been detected in vegetative shoot organs and even in the flowers [167]. Figure 4 summarizes the evidences of plant uptake and internal translocation of carbonbased nanomaterials.

Considering the above-described effects of CNTs on plants, several tentative conclusions can be formulated: the cases of positive effects on seed germination seem to be related to seed coat perforation by nanotubes and improved seed water uptake. The effects of CNTs on cell cultures are negative as well as positive, but in both cases a contact of CNTs and cells was observed. Many studies show plant responses to CNT treatments comparable with reactions induced by various biotic and abiotic stress factors. Generally, the interaction of CNTs (and other CNMs) with entire plants appears to be a highly complex process, in which three components (plant, CNMs and growth medium) are closely interlinked. Therefore, a variation in one of these components can completely change the expression profile of responses to CNT-plant interactions (Fig. 5), as a main source of contradictions and variability in different studies.

\section{Impact of graphene on plants}

Similar to other classes of nanomaterials, uptake into seeds and seedlings [172], plant growth stimulation $[173,174]$ at low concentrations (e.g. $5 \mathrm{mg} \mathrm{L}^{-1}$ ) and growth inhibition in plants exposed to higher doses $\left(\geq 50 \mathrm{mg} \mathrm{L}^{-1}\right)$ as a response to oxidative stress [175] has been also demonstrated for graphene.

A very detailed investigation of oxidative stress, induced by different concentrations of graphene oxide in faba bean $(V . f a b a)$ seedlings was performed by Anjum et al. $[176,177]$. They showed that low and high concentrations of GO applications (100, 200 and $1600 \mathrm{mg} \mathrm{L}^{-1}$ ) impaired the antioxidative glutathione metabolism [176] and increased the amount of ROS [177]. Interestingly, graphene oxide applied in moderate concentrations ( 400 and $800 \mathrm{mg} \mathrm{L}^{-1}$ ) increased the glutathione pool [176] and reduced the formation of ROS [177], which was explained by an improved seed water content. Amendments of graphene oxide to native soils also reduced the activity of soil enzymes (xylosidase, $1,4-\beta$ - $\mathrm{N}$-acetyl glucosaminidase, and phosphatase), which is probably related to its antimicrobial properties, but the microbial biomass was not affected [178]. Additionally, indirect toxicity of GO has been reported in wheat (T. aestivum) acting via increased phytotoxicity of arsenic (As) [179]. Mechanical damage of the cell wall and plasma membrane caused by the graphene oxide sheets, contributed to increased As uptake, which led to toxicity and further changes in metabolism. Similarly, mechanical damages of cell wall and other organelles (chloroplasts) due to GO treatments as well as enhanced formation of ROS have been detected in algal cells $[180,181]$. Thus, the published data suggest that the main mechanisms of graphene toxicity are based on (i) mechanical damage of cells and tissues caused by the sharp edges of graphene sheets and (ii) formation of ROS which in small doses can also induce hormetic effects.

\section{Methodological considerations}

Many authors emphasize that in studies on nanomaterial toxicity, specific methodological considerations should be taken into account. Very often these studies have been criticized for the use of unrealistically high concentrations of the applied carbon-based nanomaterials. By analyzing the available literature on carbon nanomaterial-plant interactions, it can be concluded that the concentration of applied fullerenes, nanotubes, graphene and their derivatives is highly variable, ranging from the lowest applied concentration of $0.001 \mathrm{mg}$ fullerenes $L^{-1}$ [142] to the highest of $5000 \mathrm{mg}$ carbon nanotubes $\mathrm{L}^{-1}$ [125]. Considering each group of nanomaterials separately, it turns out that fullerenes were tested in a concentration range between 0.001 and $200 \mathrm{mg} \mathrm{L}^{-1}$ [142], followed by graphene concentrations from 5 [173] to $2000 \mathrm{mg} \mathrm{L}^{-1}$ [175], and carbon nanotubes applied in a range from $5 \mathrm{mg} \mathrm{L}^{-1}$ [158] up to $5000 \mathrm{mg} \mathrm{L}^{-1}$ [125] (Fig. 6). The real concentrations of carbon-based nanomaterials in different environmental compartments are yet unknown but modeled release rates of carbonbased nanomaterials into soils (for EU) are higher for CNTs (1.51 ng kg $\mathrm{gear}^{-1}$ ), compared to fullerenes (0.058 $\mathrm{ng} \mathrm{kg}^{-1}$ year $\left.^{-1}\right)$. However, certain management strategies such as sludge soil applications can dramatically increase these values (CNTs: $73.6 \mathrm{ng} \mathrm{kg}^{-1}$ year $^{-1}$, fullerenes: $2.2 \mathrm{ng} \mathrm{kg}^{-1}$ year $^{-1}$ ) [182]. These estimates provide important basic information concerning the range of potentially expected inputs, although the long-term behavior and persistence of CNMs in various environmental compartments still remains to be determined. At least some studies demonstrate the environmental transformations of CNMs including soil sorption and microbial degradation [146, 183-186] which can finally reduce the real CNM bioavailability. 


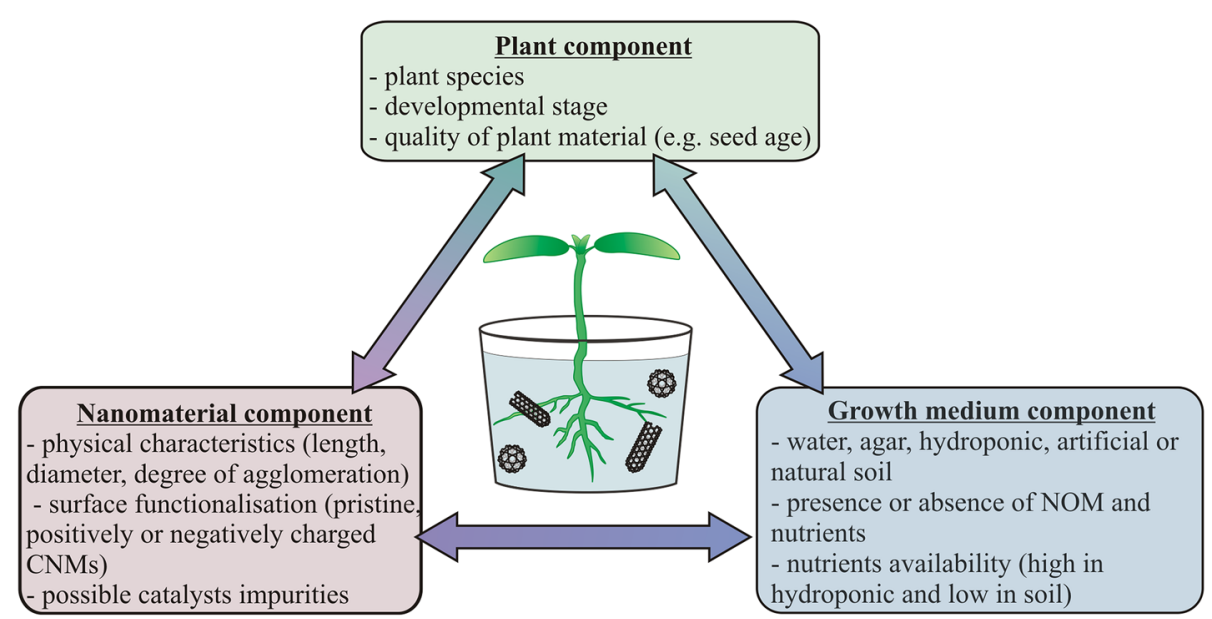

Fig. 5 Relationships between three components (plant, carbon nanomaterial and growth medium) as a complex system determining effects of nanomaterial influence of plant development

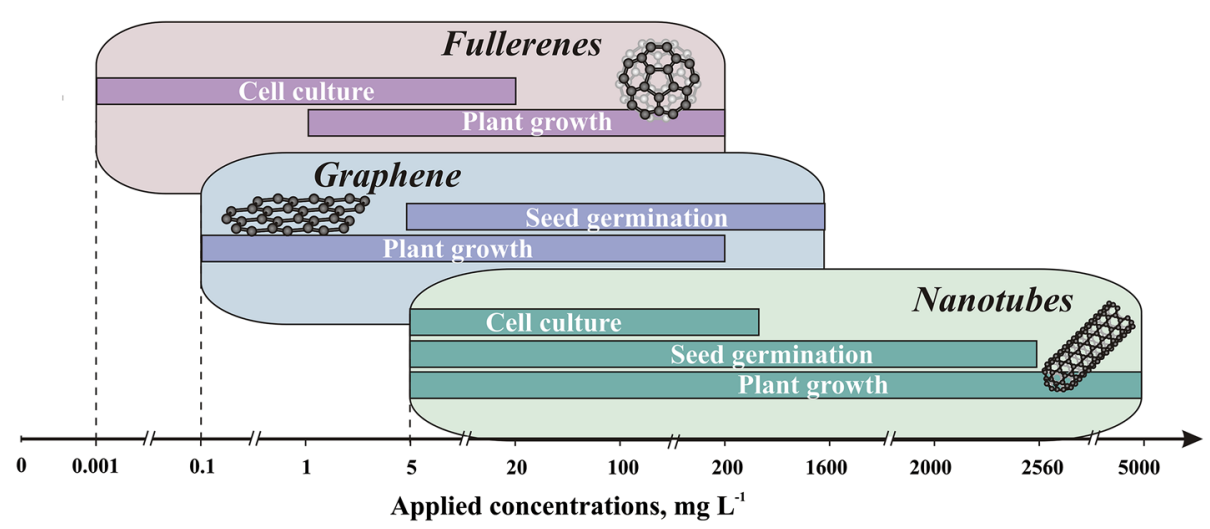

Fig. 6 Range of carbon-based nanomaterial concentrations, used in plant toxicity studies

For ecotoxicological studies, it is recommended to use an appropriate range of CNM concentrations with respect to the study objectives. However, the experimental concentrations of CNMs used to investigate potential consequences of CNM release as environmental contaminations (ppb range), in many cases largely exceed the levels arising from model calculations (ppt range). On the other hand, in studies aiming at the development of agricultural or biotechnological CNM applications, substantially higher concentrations frequently need to be investigated according to the envisaged product design. Therefore, a clear definition of study objectives is essential to obtain valuable results.

Another important methodological issue is the availability of reliable techniques for CNMs detection in plant tissues. Qualitative methods of CNM detection in plant samples comprise light microscopy, transmission and scanning electron microscopy (TEM and SEM) able to detect carbon nanotubes, fullerenes and graphene particles in plant samples. Light microscopy was used as an easily available technique for visualization of MWCNT aggregates in contact with Arabidopsis (A. thaliana) cell cultures or for the detection of MWCNTs at the root surface of red spinach (A. tricolor) seedlings, grown in CNT-amended nutrient solution [122]. However, light microscopy only allows detection of large CNMs aggregates but not individual CNM particles.

A significantly higher resolution can be obtained using TEM, which has been used for detection of graphene oxide in the tissues of wheat ( $T$. aestivum) seedlings [179], the presence of graphene inside the husk of tomato (S. lycopersicum) seeds [172], localization of C70 in rice 
(O. sativa) leaves [145], MWCNTs in root and leaves of maize (Z. mays) and soybean (G. max.) seedlings [129]. Challenges related to TEM comprise low contrast between CNMs and plant tissue structures [130, 151], a complicated sample preparation and the need for analysis of large numbers of samples. Use of fluorescent labels attached to CNTs can significantly improve the feasibility of microscopic techniques [187]. However, this type of chemical CNT functionalization can also lead to alterations of their physicochemical properties associated with altered effects on plants [166].

Scanning electron microscopy is another technique to visualize CNMs: it has been used to detect graphene sheets at the root surface of red spinach (A. tricolor), cabbage (B. oleracea) and tomato (S. lycopersicum) seedlings [175] and of MWCNTs associated with red spinach $(A$. tricolor) roots [122]. However, the resolution of SEM techniques is often smaller than in TEM. Visualization of $\mathrm{CNMs}$ at the surface or inside plant tissues can provide important information on interactions of CNMs with plant cells and cell structures, internalization mechanisms of CNMs, and transport and distribution of CNMs within the plant, with particular importance for the development of vehicle systems.

Alternative technique to identify the presence of carbon nanotubes in plant samples is Raman spectroscopy. In contrast to TEM, this method does not produce false negative results, but it cannot provide detailed information on intracellular CNM location. Therefore, both techniques are frequently used for complementary analyses. A combination of Raman spectroscopy and TEM was employed for detection of CNTs in tomato (Solanum lycopersicum) [154], wheat (Triticum aestivum) [171] and red spinach (Amaranthus tricolor) [122] seedlings and in tobacco (Nicotiana tabacum) cell cultures [165].

A promising novel approach for detection of MWCNTs in plant tissues is based on a combination of photothermal and photoacoustic mapping developed by Khodakovskaya et al. [151]. The method has demonstrated high sensitivity, and the obtained results were confirmed by optical imaging. In another study, infra-red (IR) spectroscopy was used for detection of fullerols in bitter melon [143], since fullerols exhibit specific infra-red absorption features.

Despite numerous examples of evidence for the uptake of carbon nanomaterials into plant organs, only limited information exists concerning the quantities of CNMs taken up by plants. However, in the recent past significant progress has been made in the development of techniques for CNMs quantification; fullerene $\mathrm{C} 60$ has been quantified in zucchini (C. pepo) stems using high-performance liquid chromatography (HPLC) with UV-vis spectroscopic detection [141]. Another method for CNT quantification inside plant samples, based on microwaveinduced heating [188] has demonstrated extraordinarily high accuracy associated with low detection limits $(<0.1 \mu \mathrm{g})$ and is now registered as a patent [189]. Also, radio-labeled CNMs have been employed to quantify CNMs in plant tissues. Application of ${ }^{14} \mathrm{C}$-labeled C60 to radish (Raphanus sativus) grown in sand and hydroponic culture, revealed plant uptake of $7 \%$ of the applied fullerene dosage. In a study with wheat (T. aestivum) and rapeseed (B. napus) exposed to ${ }^{14} \mathrm{C}$-radiolabeled MWCNTs (10-100 $\left.\mathrm{mg} \mathrm{L}^{-1}\right)$ in a hydroponic culture medium [171] it was demonstrated that less than $0.005 \%$ o $\left(\approx 200 \mathrm{ng} \mathrm{g}^{-1}\right.$ plant dry matter) of the total applied nanomaterial, was taken up and translocated within the plants without beneficial or detrimental effects. The high discrepancy between the externally applied amount of CNTs and the fraction really taken up by the plants, as well as typical features of carbon nanomaterials, such as agglomeration or sedimentation in suspensions and surface adsorption to solid substrates, which can vary considerably depending on the composition of the incubation media [152], demonstrate that the simple indication of application concentrations is easy to use but only of little informative value with respect to the real effective dosage.

Moreover, frequently pristine nanomaterials are used in test systems to investigate their interactions with living organisms. This scenario hardly reflects realistic natural conditions, since depending on the composition of the incubation medium, carbon nanomaterials can undergo significant conformational changes (e.g. agglomeration) with significant impact on their properties in terms of bioavailability or toxicity $[118,152]$. To define realistic application conditions, much more information is required concerning the behavior of the various types of nanomaterials in soils and planting substrates. For comparative analyses, the development of standardized test systems would be urgently needed. It has been also recommended to pay more attention to selected controls [130] by also including positive controls in addition to the commonly used negative controls, as well as other carbon (activated carbon) and non-carbon (contaminants in $\mathrm{CNTs}$ ) controls that will eliminate any possible artifacts.

\section{Conclusion}

Nanotechnology develops rapidly and promises innovations in many fields of science and technology. Nanomaterials, including carbon-based nanomaterials, are ready to be produced on a large, industrial scale for a wide range of application fields including the environmental and agricultural sectors. However, a surprisingly limited body of information exists concerning the real concentrations and behavior of these materials in natural environments and their interactions with living organisms as a prerequisite 
for safety evaluations. This is further complicated by the wide range of nanomaterials with different properties and by conformational changes of carbon nanomaterials during interactions with the various constituents of different incubation media (e.g. agglomeration) with potential impact on bioavailability and toxicity [122, 171]. Apart from these limitations however, at least some principal properties of carbon nanomaterials, relevant for their interactions with plants have been identified:

1. Most carbon nanomaterials can be taken up by plants. This is frequently associated also with internal translocation;

2. Small amounts of absorbed nanomaterials can induce physiological responses;

3. At higher external concentrations, frequently detrimental effects on plant growth are observed, while lower levels of carbon nanomaterials $\left(<100 \mathrm{mg} \mathrm{L}^{-1}\right)$ exert beneficial or no effects;

4. Induction of oxidative stress by formation of ROS seems to be a major common mechanism of phytotoxicity induced by carbon nanomaterials, while beneficial effects are probably based on hormesis, which is frequently observed during exposure to toxic agents at sub-toxic levels (e.g. glyphosate, $\mathrm{Al}^{3+}$, pathogens), and often based on induction and strengthening of stress defense systems [176, 177]; in the case of improved seed germination there is also a stimulation of water uptake;

5. Chemical (functionalization) or conformational (agglomeration) modifications of carbon nanomaterials can significantly influence their toxicity potential;

6. In many studies of $\mathrm{CNM}$ phytotoxicity tested dosages significantly exceed the expected environmental concentrations.

As a major challenge for the future, a more comprehensive and systematic survey of the key factors important for interactions of the various carbon nanomaterials with living organisms and the environment will be important for both risk evaluation and the characterization of potential applications.

\section{Additional file}

Additional file 1. List of patents for nano-carbon containing agricultural products.

\footnotetext{
Abbreviations

CNMs: carbon nanomaterials; CNTs: carbon nanotubes; SWCNTs: single-walled nanotubes; DWCNTs: double-walled carbon nanotubes; MWCNTs: multiwalled nanotubes; fSWCNTs: functionalized single-walled carbon nanotubes; oMWCNTs: oxidized multi-walled carbon nanotubes; wsMWCNTs: water soluble MWCNTs; C60, C70: fullerenes; CVD: chemical vapor deposition; AC:
}

activated carbon; DDT: dichlorodiphenyltrichloroethane; DDE: dichlorodiphenyldichloroethylene; FMAD: fullerene-malonic acid derivative; DNA: deoxyribonucleic acid; ROS: reactive oxygen species; SOD: superoxide dismutase; GO: graphene oxide; DI water: deionized water; MS medium: Murashige and Skoog medium; CNPs: carbon nanoparticles; NOM: natural organic matter; GSH: glutathione; TEM: transmission electron microscopy; SEM: scanning electron microscopy; IR spectroscopy: infra-red spectroscopy; HPLC: high performance liquid chromatography.

\section{Authors' contributions}

OZ wrote the manuscript and prepared figures and tables. The manuscript was edited and improved by both authors. All authors read and approved the final manuscript.

\section{Acknowledgements}

The author (OZ) would like to thank the Ministry of Science, Research and the Arts of Baden-Württemberg and the Education, Audiovisual and Culture Executive Agency of the European Union for financial support. Furthermore, the authors are grateful to two anonymous referees for helpful remarks.

\section{Competing interests}

The authors declare that they have no competing interests.

Received: 23 December 2015 Accepted: 26 April 2016

Published online: 19 July 2016

\section{References}

1. Roston E. The carbon age. How life's core element has become civilization's greatest threat. New York: Walker \& Co.; 2009.

2. In JB, Noy A. Chapter 3. Nanotechnology's wonder material: synthesis of carbon nanotubes. In: Ko SH, Grigoropoulos CP, editors. Hierarchical nanostructures for energy devices. Cambridge: Royal Society of Chemistry; 2014. p. 26-58.

3. Novoselov K. Beyond the wonder material. Phys World. 2009;22:27-30

4. Peng Q, Dearden AK, Crean J, Han L, Liu S, Wen X, De S. New materials graphyne, graphdiyne, graphone, and graphane: review of properties, synthesis, and application in nanotechnology. Nanotechnol Sci Appl. 2014;7:1-29.

5. Kah M, Hofmann T. The challenge: carbon nanomaterials in the environment: new threats or wonder materials? Environ Toxicol Chem. 2015;34:954.

6. Grand View Research, Inc. Carbon nanotubes (CNT) market analysis by product [single walled carbon nanotubes (SWCNT), multi walled carbon nanotubes (MWCNT)], by application (polymers, energy, electrical and electronics) and segment forecasts to 2022.

7. Kozarsky R, editor. Searching for profits at the intersection of nanotech and electronics. Santa Clara; January 28, 2014.

8. European Comission. European comission recommendations of 18 October 2011 on the definition of nanomaterial. Off J Eur Un. 2011:54:38-40.

9. De Volder MF, Tawfick SH, Baughman RH, Hart AJ. Carbon nanotubes: present and future commercial applications. Science. 2013;339:535-9.

10. Khare R, Bose S. Carbon nanotube based composites-a review. J Minerals Mater Charact Eng. 2005:4:31-46.

11. Singh H, Srivastava M. Fullerenes: synthesis, separation, characterization, reaction chemistry, and applications-a review. Energy Sources. 1995;17:615-40.

12. Kroto HW, Heath JR, O'Brien SC, Curl RF, Smalley RE. C60: buckminsterfullerene. Nature. 1985;318:162-3.

13. Yadav BC, Kumar R. Structure, properties and applications of fullerenes. Int J Nanotechnol Appl. 2008;2:15-24.

14. Zhang R, Zhang Y, Zhang Q, Xie H, Qian W, Wei F. Growth of half-meter long carbon nanotubes based on Schulz-Flory distribution. ACS Nano. 2013;7:6156-61.

15. Krätschmer W, Lamb LD, Fostiropoulos K, Huffman DR. Solid C60: a new form of carbon. Nature. 1990;347:354-8. 
16. Krätschmer W. The story of making fullerenes. Nanoscale. 2011;3:2485-9.

17. Churilov GN. Synthesis of fullerenes and other nanomaterials in arc discharge. Fullerenes, Nanotubes, Carbon Nanostruct. 2008;16:395-403.

18. Gore, Sane A. Flame synthesis of carbon nanotubes. Rijeka: INTECH Open Access Publisher; 2011.

19. Kumar M, Ando Y. Chemical vapor deposition of carbon nanotubes: a review on growth mechanism and mass production. J Nanosci Nanotech. 2010;10:3739-58.

20. Zhang Q, Huang J, Zhao M, Qian W, Wei F. Carbon nanotube mass production: principles and processes. ChemSusChem. 2011;4:864-89.

21. Morsy M, Helal M, El-Okr M, Ibrahim M. Preparation, purification and characterization of high purity multi-wall carbon nanotube. Spectrochim Acta A Mol Biomol Spectrosc. 2014;132:594-8.

22. Matsuzawa Y, Takada Y, Kodaira T, Kihara H, Kataura H, Yoshida M. Effective nondestructive purification of single-walled carbon nanotubes based on high-speed centrifugation with a photochemically removable dispersant. J Phys Chem C. 2014;118:5013-9.

23. Novoselov KS, Geim AK, Morozov SV, Jiang D, Zhang Y, Dubonos SV, Grigorieva IV, Firsov AA. Electric field effect in atomically thin carbon films. Science. 2004;306:666-9.

24. Novoselov KS, Fal'Ko VI, Colombo L, Gellert PR, Schwab MG, Kim K. A roadmap for graphene. Nature. 2012;490:192-200.

25. Jiao L, Zhang L, Wang $X$, Diankov G, Dai H. Narrow graphene nanoribbons from carbon nanotubes. Nature. 2009;458:877-80.

26. Hirsch A, Vostrowsky O. Functionalization of carbon nanotubes. Top Curr Chem. 2005;245:193-237.

27. Hernández-Fernández P, Montiel M, Ocón P, de la Fuente JLG, GarcíaRodríguez S, Rojas S, Fierro JL. Functionalization of multi-walled carbon nanotubes and application as supports for electrocatalysts in protonexchange membrane fuel cell. Appl Catal B. 2010;99:343-52.

28. Velasco-Santos C. Naturally produced carbon nanotubes. Chem Phys Lett. 2003;373:272-6.

29. MacKenzie KJ, See CH, Dunens OM, Harris AT. Do single-walled carbon nanotubes occur naturally? Nat Nano. 2008;3:310.

30. Su DS, Chen X. Natural lavas as catalysts for efficient production of carbon nanotubes and nanofibers. Angew Chem Int Ed Engl. 2007:46:1823-4.

31. Mracek J, D. Fagan R, M. Stengelin R, Hesjedal T. Are carbon nanotubes a naturally occurring material? Hints from methane CVD using lava as a catalyst. CNANO. 2011;7:294-6.

32. Buseck PR, Tsipursky SJ, Hettich R. Fullerenes from the geological environment. Science. 1992;257:215-7.

33. Parthasarathy G, Srinivasan R, Vairamani M, Ravikumar K, Kunwar AC. Occurrence of natural fullerenes in low grade metamorphosed proterozoic shungite from Karelia, Russia. Geochimica et Cosmochimica Acta. 1998;62:3541-4

34. Misra KS, Hammond MR, Phadke AV, Plows F, Reddy US, Reddy IV, Parthasarathy G, Rao CRM, Gohain BN, Gupta D. Occurrence of fullerence bearing shungite suite rock in Mangampeta area, Cuddapah District, Andhra Pradesh. J Geol Soc India. 2007:69:25-8.

35. Reznikov VA, Polekhovskiǐ YS. Amorphous shungite carbon: a natural medium for the formation of fullerenes. Tech Phys Lett. 2000;26:689-93.

36. Becker L, Bada JL, Winans RE, Bunch TE. Fullerenes in Allende meteorite. Nature. 1994;372:507.

37. Andrade K, Guerra S, Debut A, Andrade K, Guerra S, Debut A. Fullerene-based symmetry in Hibiscus rosa-sinensis pollen. PLoS One. 2014;9:e102123.

38. Ahmad K, Pan W. Microstructure-toughening relation in alumina based multiwall carbon nanotube ceramic composites. J Eur Ceram Soc. 2015:35:663-71.

39. Nasibulin AG, Shandakov SD, Nasibulina LI, Cwirzen A, Mudimela PR, Habermehl-Cwirzen K, Grishin DA, Gavrilov YV, Malm JE, Tapper U, Tian Y, Penttala V, Karppinen MJ, Kauppinen El. A novel cement-based hybrid material. New J Phys. 2009;11:023013.

40. Ma P, Zhang Y. Perspectives of carbon nanotubes/polymer nanocomposites for wind blade materials. Renew Sustain Energy Rev. 2014;30:651-60

41. Loh KJ, Ryu D. 11-multifunctional materials and nanotechnology for assessing and monitoring civil infrastructures. In: Wang M, Lynch J, Sohn H, editors. Sensor technologies for civil infrastructures:
Woodhead Publishing Series in Electronic and Optical Materials. Sawston: Woodhead Publishing; 2014. p. 295-326.

42. Ng K, Lam W, Pichiah S. A review on potential applications of carbon nanotubes in marine current turbines. Renew Sustain Energy Rev. 2013;28:331-9.

43. Peddini SK, Bosnyak CP, Henderson NM, Ellison CJ, Paul DR. Nanocomposites from styrene-butadiene rubber (SBR) and multiwall carbon nanotubes (MWCNT) part 1: morphology and rheology. Polymer. 2014;55:258-70.

44. Luinge $\mathrm{H}$. Nano-modified materials in aviation: Carbon nanotubes for lighter airplane outer shells. Konstruktion. 2011;IW10.

45. Tan D, Zhang Q. Research of carbon nanotubes/polymer composites for sports equipment. Adv Intell Soft Comput. 2011;119:137-46.

46. Tong J, Zimmerman MC, Li S, Yi X, Luxenhofer R, Jordan R, Kabanov AV. Neuronal uptake and intracellular superoxide scavenging of a fullerene (C60)-poly(2-oxazoline)s nanoformulation. Biomaterials. 2011;32:3654-65.

47. Uritu CM, Varganici CD, Ursu L, Coroaba A, Nicolescu A, Dascalu Al, Peptanariu D, Stan D, Constantinescu CA, Simion V, Calin M, Maier SS, Pinteala M, Barboiu M. Hybrid fullerene conjugates as vectors for DNA cell-delivery. J Mater Chem B. 2015;3:2433-46.

48. Kato S, Taira H, Aoshima H, Saitoh Y, Miwa N. Clinical evaluation of fullerene-C 60 dissolved in squalane for anti-wrinkle cosmetics. J Nanosci Nanotechnol. 2010;10:6769-74.

49. Bergeson LL, Cole MF. Fullerenes used in skin creams. Nanotechnol Law Bus. 2012;9:114-20.

50. Benn T, Cavanagh B, Hristovski K, Posner JD, Westerhoff P. The release of nanosilver from consumer products used in the home. J Env Qual. 2010;39:1875-82.

51. Choi W, Lahiri I, Seelaboyina R, Kang YS. Synthesis of graphene and its applications: a review. Crit Rev Solid State Mater Sci. 2010;35:52-71.

52. Das R, Ali ME, Hamid SBA, Ramakrishna S, Chowdhury ZZ. Carbon nanotube membranes for water purification: a bright future in water desalination. Desalination. 2014;336:97-109.

53. Qu X, Alvarez PJJ, Li Q. Applications of nanotechnology in water and wastewater treatment. Water Res. 2013;47:3931-46.

54. Liu X, Wang M, Zhang S, Pan B. Application potential of carbon nanotubes in water treatment: a review. J Environ Sci (China). 2013:25:1263-80.

55. Smith SC, Rodrigues DF. Carbon-based nanomaterials for removal of chemical and biological contaminants from water: a review of mechanisms and applications. Carbon. 2015;91:122-43.

56. Yan H, Gong A, He H, Zhou J, Wei Y, LV L. Adsorption of microcystins by carbon nanotubes. Chemosphere. 2006;62:142-8.

57. Li Y, Wang S, Wei J, Zhang X, Xu C, Luan Z, Wu D, Wei B. Lead adsorption on carbon nanotubes. Chem Phys Lett. 2002:357:263-6.

58. Dichiara AB, Webber MR, Gorman WR, Rogers RE. Removal of Copper Ions from Aqueous Solutions via Adsorption on Carbon Nanocomposites. ACS Appl Mater Interfaces. 2015;7:15674-80.

59. Zhang L, Song X, Liu X, Yang L, Pan F, Lv J. Studies on the removal of tetracycline by multi-walled carbon nanotubes. Chem Eng J. 2011;178:26-33.

60. Deng J, Shao Y, Gao N, Deng Y, Tan C, Zhou S, Hu X. Multiwalled carbon nanotubes as adsorbents for removal of herbicide diuron from aqueous solution. Chem Eng J. 2012;193:339-47.

61. Zheng $X$, Su Y, Chen Y, Wei Y, Li M, Huang $H$. The effects of carbon nanotubes on nitrogen and phosphorus removal from real wastewater in the activated sludge system. RSC Adv. 2014:4:45953-9.

62. Mishra A, Clark JH. Green materials for sustainable water remediation and treatment. Cambridge: Royal Society of Chemistry; 2013.

63. Srivastava $M$, Abhilash PC, Singh N. Remediation of lindane using engineered nanoparticles. J Biomed Nanotechnol. 2011;7:172-4.

64. Wang L, Fortner JD, Hou L, Zhang C, Kan AT, Tomson MB, Chen W. Contaminant-mobilizing capability of fullerene nanoparticles (nC60): effect of solvent-exchange process in nC60 formation. Environ Toxicol Chem. 2013;32:329-36.

65. Yoo J, Ozawa H, Fujigaya T, Nakashima N. Evaluation of affinity of molecules for carbon nanotubes. Nanoscale. 2011;3:2517-22.

66. Choi WS, Yang HM, Koo HY, Lee H, Lee YB, Bae TS, Jeon IC. Smart microcapsules encapsulating reconfigurable carbon nanotube cores. Adv Funct Mater. 2010;20:820-5.

67. Wang H, Ma H, Zheng W, An D, Na C. Multifunctional and recollectable carbon nanotube ponytails for water purification. ACS Appl Mater Interfaces. 2014;6:9426-34. 
68. Jung JH, Hwang GB, Lee JE, Bae GN. Preparation of airborne Ag/CNT hybrid nanoparticles using an aerosol process and their application to antimicrobial air filtration. Langmuir. 2011;27:10256-64

69. Al-Hakami SM, Khalil AB, Laoui T, Atieh MA. Fast disinfection of Escherichia coli bacteria using carbon nanotubes interaction with microwave radiation. Bioinorg Chem Appl. 2013;2013:458943.

70. Upadhyayula VKK, Deng S, Mitchell MC, Smith GB. Application of carbon nanotube technology for removal of contaminants in drinking water: a review. Sci Total Environ. 2009;408:1-13.

71. Das R, Abd Hamid SB, Ali ME, Ismail AF, Annuar MSM, Ramakrishna S. Multifunctional carbon nanotubes in water treatment: the present, past and future. Desalination. 2014;354:160-79.

72. Parisi C, Vigani M, Rodríguez-Cerezo E, editors. Proceedings of a workshop on "Nanotechnology for the agricultural sector: from research to the field". Luxembourg; 2014.

73. Khot LR, Sankaran S, Maja JM, Ehsani R, Schuster EW. Applications of nanomaterials in agricultural production and crop protection: a review. Crop Prot. 2012;35:64-70.

74. Hong J, Peralta-Videa JR, Gardea-Torresdey JL. Nanomaterials in agricultural production: benefits and possible threats? In: Shamim N, Sharma VK, editors. Sustainable nanotechnology and the environment: advances and achievements. Washington, D.C: American Chemical Society; 2013. p. 73-90.

75. Gogos A, Knauer K, Bucheli TD. Nanomaterials in plant protection and fertilization: current state, foreseen applications, and research priorities. J Agric Food Chem. 2012;60:9781-92.

76. Sarlak N, Taherifar A, Salehi F. Synthesis of nanopesticides by encapsulating pesticide nanoparticles using functionalized carbon nanotubes and application of new nanocomposite for plant disease treatment. J Agric Food Chem. 2014;62:4833-8.

77. Suresh Kumar RS, Shiny PJ, Anjali CH, Jerobin J, Goshen KM, Magdassi S, Mukherjee A, Chandrasekaran N. Distinctive effects of nanosized permethrin in the environment. Environ Sci Pollut Res Int. 2013;20:2593-602.

78. Pereira A, Grillo R, Mello NF, Rosa AH, Fraceto LF. Application of poly(epsilon-caprolactone) nanoparticles containing atrazine herbicide as an alternative technique to control weeds and reduce damage to the environment. J Hazard Mater. 2014;268:207-15.

79. Auernhammer $\mathrm{H}$. Precision farming - the environmental challenge. Comput Electron Agric. 2001;30:31-43.

80. González-Melendi P, Fernández-Pacheco R, Coronado MJ, Corredor E, Testillano PS, Risueño MC, Marquina C, Ibarra MR, Rubiales D, Pérez-deLuque A. Nanoparticles as smart treatment-delivery systems in plants: assessment of different techniques of microscopy for their visualization in plant tissues. Ann Bot. 2008;101:187-95.

81. Zhang M, Gao B, Chen J, Li Y, Creamer AE, Chen H. Slow-release fertilizer encapsulated by graphene oxide films. Chem Eng J. 2014;255:107-13.

82. Liu Q, Chen B, Wang Q, Shi X, Xiao Z, Lin J, Fang X. Carbon nanotubes as molecular transporters for walled plant cells. Nano Lett. 2009;9:1007-10.

83. Giraldo JP, Landry MP, Faltermeier SM, MCNicholas TP, Iverson NM, Boghossian AA, Reuel NF, Hilmer AJ, Sen F, Brew JA, Strano MS. Plant nanobionics approach to augment photosynthesis and biochemical sensing. Nat Mater. 2014;13:400-8.

84. Khan AJ, Khan RA, Singh VM, Newati SJ, Yusuf M. In silico designed, self-assembled, functionalized single-walled carbon nanotubes and deoxyribose nucleic acids (f-SW-CNT-DNA) bioconjugate as probable biomolecular transporters. J Bionanoscience. 2013;7:530-50.

85. Das M, Singh RP, Datir SR, Jain S. Intranuclear drug delivery and effective in vivo cancer therapy via estradiol-peg-appended multiwalled carbon nanotubes. Mol Pharm. 2013;10:3404-16.

86. Zia ul Quasim S, Ali Ml, Irfan S, Naveed A. Advances in drug delivery system: carbon nanotubes. Res J Pharm Technol. 2013;6:125-9.

87. Revathi S, Vuyyuru M, Dhanaraju MD. Carbon nanotube: a flexible approach for nanomedicine and drug delivery. Asian J Pharm Clin Res. 2015;8:25-31.

88. Rieger C, Kunhardt D, Kaufmann A, Schendel D, Huebner D, Erdmann K, Propping S, Wirth MP, Schwenzer B, Fuessel S, Hampel S. Characterization of different carbon nanotubes for the development of a mucoadhesive drug delivery system for intravesical treatment of bladder cancer. Int J Pharm. 2015;479:357-63.

89. Sharifi S, Hashemi MM, Mosslemin MH, Mollaamin F. Carbon nanotube as a specific career in drug delivery for antioxidant molecule in Malva Sylvestris L. plant. J Comput Theor Nanosci. 2014;11:1178-83.

90. Schmitt H, Creton N, Prashantha K, Soulestin J, Lacrampe MF, Krawczak P. Melt-blended halloysite nanotubes/wheat starch nanocomposites as drug delivery system. Polym Eng Sci. 2015;55:573-80.

91. Jain S. Toxicity issues related to biomedical applications of carbon nanotubes. J Nanomedic Nanotechnol. 2012;03:5.

92. Wang X, Liu X, Chen J, Han H, Yuan Z. Evaluation and mechanism of antifungal effects of carbon nanomaterials in controlling plant fungal pathogen. Carbon. 2014;68:798-806.

93. Chen J, Peng H, Wang X, Shao F, Yuan Z, Han H. Graphene oxide exhibits broad-spectrum antimicrobial activity against bacterial phytopathogens and fungal conidia by intertwining and membrane perturbation. Nanoscale. 2014;6:1879-89.

94. Liu S, Hu M, Zeng TH, Wu R, Jiang R, Wei J, Wang L, Kong J, Chen Y. Lateral dimension-dependent antibacterial activity of graphene oxide sheets. Langmuir. 2012;28:12364-72.

95. Hui L, Piao J, Auletta J, Hu K, Zhu Y, Meyer T, Liu H, Yang L. Availability of the basal planes of graphene oxide determines whether it is antibacterial. ACS Appl Mater Interfaces. 2014;6:13183-90.

96. Mangadlao JD, Santos CM, Felipe MJL, De Leon ACC, Rodrigues DF, Advincula RC. On the antibacterial mechanism of graphene oxide (GO) Langmuir-Blodgett films. Chem Commun. 2015;51:2886-9.

97. Akhavan O, Ghaderi E. Toxicity of graphene and graphene oxide nanowalls against bacteria. ACS Nano. 2010;4:5731-6.

98. Liu S, Zeng TH, Hofmann M, Burcombe E, Wei J, Jiang R, Kong J, Chen Y. Antibacterial activity of graphite, graphite oxide, graphene oxide, and reduced graphene oxide: membrane and oxidative stress. ACS Nano. 2011:5:6971-80.

99. Li J, Wang G, Zhu H, Zhang M, Zheng X, Di Z, Liu X, Wang X. Antibacterial activity of large-area monolayer graphene film manipulated by charge transfer. Sci Rep. 2014;4:4359.

100. Ion I, Culetua A, Gherase D, Sirbu F, Ion AC. Environmental applications of carbon-based nanomaterials. Acetylcholinesterase biosensors for organophosphate pesticide analysis. In: Ion A, Dascalu D, Carja G, Cirea M, editors. New Applications of Nanomaterials. Bucharest: Academiei Române; 2014. p. 33-51.

101. Wu L, Fu X, Liu H, Li J, Song Y. Comparative study of graphene nanosheetand multiwall carbon nanotube-based electrochemical sensor for the sensitive detection of cadmium. Anal Chim Acta. 2014;851:43-8.

102. Taher MA, Mazaheri L, Ashkenani H, Mohadesi A, Afzali D. Determination of nickel in water, food, and biological samples by electrothermal atomic absorption spectrometry after preconcentration on modified carbon nanotubes. J AOAC Int. 2014;97:225-31.

103. Guerin H, Le Poche H, Pohle R, Syavoch Bernard L, Buitrago E, Ramos R, Dijon J, Ionescu AM. High-yield, in situ fabrication and integration of horizontal carbon nanotube arrays at the wafer scale for robust ammonia sensors. Carbon. 2014;78:326-38.

104. Luo M, Liu D, Zhao L, Han J, Liang Y, Wang P, Zhou Z. A novel magnetic ionic liquid modified carbon nanotube for the simultaneous determination of aryloxyphenoxy-propionate herbicides and their metabolites in water. Anal Chim Acta. 2014;852:88-96.

105. Ma G, Chen L. Development of magnetic molecularly imprinted polymers based on carbon nanotubes - Application for trace analysis of pyrethroids in fruit matrices. J Chromatogr A. 2014;1329:1-9.

106. Tabani H, Fakhari AR, Shahsavani A, Behbahani M, Salarian M, Bagheri A, Nojavan S. Combination of graphene oxide-based solid phase extraction and electro membrane extraction for the preconcentration of chlorophenoxy acid herbicides in environmental samples. J Chromatogr A. 2013;1300:227-35

107. Jackson T, Mansfield K, Saafi M, Colman T, Romine P. Measuring soil temperature and moisture using wireless MEMS sensors. Meas: J Int Meas Confed. 2008;41:381-90.

108. Ren Q, Yuan X, Huang X, Wen W, Zhao Y, Chen W. In vivo monitoring of oxidative burst on aloe under salinity stress using hemoglobin and single-walled carbon nanotubes modified carbon fiber ultramicroelectrode. Biosens Bioelectron. 2013;50:318-24.

109. Lee K, Park J, Lee M, Kim J, Hyun BG, Kang DJ, Na K, Lee CY, Bien F, Park J. In-situ synthesis of carbon nanotube-graphite electronic devices and their integrations onto surfaces of live plants and insects. Nano Lett. 2014; 14:2647-54 
110. Fadel T, Standridge S, editors. Sensor fabrication, integration, and commercialization workshop. September 11-12, 2014; Arlington.

111. Swierczewska M, Liu G, Lee S, Chen X. High-sensitivity nanosensors for biomarker detection. Chem Soc Rev. 2012;41:2641-55.

112. Sarkar T, Gao Y, Mulchandani A. Carbon nanotubes-based label-free affinity sensors for environmental monitoring. Appl Biochem Biotechnol. 2013;170:1011-25.

113. Ion AC, Ion I, Culetu A. Carbon-based nanomaterials. Environmental applications. In: Brezeanu G, lovu H, Cobianu C, Dascalu D, editors. Nanomaterials and nanostructures for various applications (In serie in Micro and Nanoengineering. V.19). Bucharest: Academiei Române; 2012. p. 31-57.

114. Global nanosensors market analysis, market size, application analysis, regional outlook, competitive strategies and forecasts, 2015 to 2022. http://www.grandviewresearch.com/industry-analysis/global-nanosensors-market. Accessed 10 Apr 2016.

115. Transparency Market Research. Nanosensors market—global industry analysis, size, share, growth, trends and forecast 2014-2020. http:// www.transparencymarketresearch.com/nanosensors-market.html. Accessed 10 Apr 2016.

116. Nowack B, Bucheli TD. Occurrence, behavior and effects of nanoparticles in the environment. Environ Pollut. 2007:150:5-22.

117. Juganson K, Ivask A, Blinova I, Mortimer M, Kahru A. NanoE-Tox: new and in-depth database concerning ecotoxicity of nanomaterials. Beilstein J Nanotechnol. 2015;6:1788-804.

118. Yan S, Zhao L, Li H, Zhang Q, Tan J, Huang M, He S, Li L. Single-walled carbon nanotubes selectively influence maize root tissue development accompanied by the change in the related gene expression. J Hazard Mater. 2013;246-247:110-8.

119. Ghosh M, Bhadra S, Adegoke A, Bandyopadhyay M, Mukherjee A. MWCNT uptake in Allium cepa root cells induces cytotoxic and genotoxic responses and results in DNA hyper-methylation. Mutat Res. 2015:774:49-58.

120. Ghosh M, Chakraborty A, Bandyopadhyay M, Mukherjee A. Multi-walled carbon nanotubes (MWCNT): induction of DNA damage in plant and mammalian cells. J Hazard Mater. 2011;197:327-36.

121. Katti DR, Sharma A, Pradhan SM, Katti KS. Carbon nanotube proximity influences rice DNA. Chem Phys. 2015;455:17-22.

122. Begum $P$, Fugetsu B. Phytotoxicity of multi-walled carbon nanotubes on red spinach (Amaranthus tricolor $\mathrm{L}$ ) and the role of ascorbic acid as an antioxidant. J Hazard Mater. 2012;243:212-22.

123. Liu Q, Zhang X, Zhao Y, Lin J, Shu C, Wang C, Fang X. Fullerene-induced increase of glycosyl residue on living plant cell wall. Environ Sci Technol. 2013:47:7490-8

124. Begum P, Ikhtiari R, Fugetsu B, Matsuoka M, Akasaka T, Watari F. Phytotoxicity of multi-walled carbon nanotubes assessed by selected plant species in the seedling stage. Appl Surf Sci. 2012;262:120-4.

125. Cañas JE, Long M, Nations S, Vadan R, Dai L, Luo M, Ambikapathi R, Lee $\mathrm{EH}$, Olszyk D. Effects of functionalized and nonfunctionalized singlewalled carbon nanotubes on root elongation of select crop species. Environ Toxicol Chem. 2008:27:1922-31.

126. Stampoulis D, Sinha SK, White JC. Assay-dependent phytotoxicity of nanoparticles to plants. Environ Sci Technol. 2009:43:9473-9.

127. Tiwari DK, Dasgupta-Schubert N, Cendejas LM, Villegas J, Carreto Montoya L, García SE. Interfacing carbon nanotubes (CNT) with plants: enhancement of growth, water and ionic nutrient uptake in maize (Zea mays) and implications for nanoagriculture. Appl Nanosci. 2014;4:577-91.

128. Lahiani MH, Dervishi E, Chen J, Nima Z, Gaume A, Biris AS, Khodakovskaya MV. Impact of carbon nanotube exposure to seeds of valuable crops. ACS Appl Mater Interfaces. 2013;5:7965-73.

129. Zhai G, Gutowski SM, Walters KS, Yan B, Schnoor JL. Charge, size, and cellular selectivity for multiwall carbon nanotubes by maize and soybean. Environ Sci Technol. 2015:49:7380-90.

130. Petersen EJ, Henry TB. Methodological considerations for testing the ecotoxicity of carbon nanotubes and fullerenes: review. Environ Toxicol Chem/SETAC. 2012;31:60-72.

131. Geraci C, Heidel D, Sayes C, Hodson L, Schulte P, Eastlake A, Brenner S. Perspectives on the design of safer nanomaterials and manufacturing processes. J Nanopart Res. 2015;17:366.
132. Burello E. Computational design of safer nanomaterials. Environ Sci: Nano. 2015;2:454-62

133. Gilbertson LM, Melnikov F, Wehmas LC, Anastas PT, Tanguay RL, Zimmerman JB. Toward safer multi-walled carbon nanotube design: establishing a statistical model that relates surface charge and embryonic zebrafish mortality. Nanotoxicology. 2015;1:10-9.

134. Kumar S, Patra AK, Datta SC, Rosin KG, Purakayastha TJ. Phytotoxicity of nanoparticles to seed germination of plants. Int J Adv Res. 2015;3:854-65.

135. Liu Q, Zhao Y, Wan Y, Zheng J, Zhang X, Wang C, Fang X, Lin J. Study of the inhibitory effect of water-soluble fullerenes on plant growth at the cellular level. ACS Nano. 2010;4:5743-8.

136. Tao X, Yu Y, Fortner JD, He Y, Chen Y, Hughes JB. Effects of aqueous stable fullerene nanocrystal (nC60) on Scenedesmus obliquus: evaluation of the sub-lethal photosynthetic responses and inhibition mechanism. Chemosphere. 2015;122:162-7.

137. Santos SMA, Dinis AM, Rodrigues DMF, Peixoto F, Videira RA, Jurado AS. Studies on the toxicity of an aqueous suspension of C60 nanoparticles using a bacterium (gen. Bacillus) and an aquatic plant (Lemna gibba) as in vitro model systems. Aquat Toxicol. 2013;142-143:347-54.

138. De La Torre-Roche R, Hawthorne J, Deng Y, Xing B, Cai W, Newman L, Wang Q, Ma X, Helmi H, White JC. Multiwalled carbon nanotubes and $c$ 60 fullerenes differentially impact the accumulation of weathered pesticides in four agricultural plants. Environ Sci Technol. 2013;7:12539-47.

139. Kelsey JW, White JC. Effect of C60 fullerenes on the accumulation of weathered $p, p^{\prime}$-DDE by plant and earthworm species under single and multispecies conditions. Environ Toxicol Chem/SETAC. 2013;32:1117-23.

140. Ma X, Wang C. Fullerene nanoparticles affect the fate and uptake of trichloroethylene in phytoremediation systems. Environ Eng Sci. 2010;27:989-92

141. De La Torre-Roche R, Hawthorne J, Deng Y, Xing B, Cai W, Newman LA, Wang C, Ma X, White JC. Fullerene-enhanced accumulation of $p, p^{\prime}-D D E$ in agricultural crop species. Environ Sci Technol. 2012;46:9315-23.

142. Gao J, Wang Y, Folta KM, Krishna V, Bai W, Indeglia P, Georgieva A, Nakamura H, Koopman B, Moudgil B. Polyhydroxy fullerenes (fullerols or fullerenols): beneficial effects on growth and lifespan in diverse biological models. PLoS One. 2011;6:e19976.

143. Kole C, Kole P, Randunu KM, Choudhary P, Podila R, Ke PC, Rao AM, Marcus RK. Nanobiotechnology can boost crop production and quality: first evidence from increased plant biomass, fruit yield and phytomedicine content in bitter melon (Momordica charantia). BMC Biotechnol. 2013;13:1.

144. Beuerle F, Lebovitz R, Hirsch A. Antioxidant Properties of Water-Soluble Fullerene Derivatives. In: Cataldo F, Da Ros T, editors. Medicinal chemistry and pharmacological potential of fullerenes and carbon nanotubes. Dordrecht: Springer; 2008

145. Lin S, Reppert J, Hu Q, Hudson JS, Reid ML, Ratnikova TA, Rao AM, Luo H, Ke PC. Uptake, translocation, and transmission of carbon nanomaterials in rice plants. Small. 2009;5:1128-32.

146. Avanasi R, Jackson WA, Sherwin B, Mudge JF, Anderson TA. C60 fullerene soil sorption, biodegradation, and plant uptake. Environ Sci Technol. 2014:48:2792-7.

147. Pourkhaloee A, Haghighi M, Saharkhiz MJ, Jouzi H, Doroodmand MM. Carbon nanotubes can promote seed germination via seed coat penetration. Seed Technol. 2011;33:155-69.

148. Yuan H, Hu S, Huang P, Song H, Wang K, Ruan J, He R, Cui D. Single walled carbon nanotubes exhibit dual-phase regulation to exposed arabidopsis mesophyll cells. Nanoscale Res Lett. 2010;297:787.

149. Shen C, Zhang Q, Li J, Bi F, Yao N. Induction of programmed cell death in Arabidopsis and rice by single-wall carbon nanotubes. Am J Bot. 2010:97:1602-9.

150. Flores D, Chaves JS, Chacón R, Schmidt A. A novel technique using SWCNTs to enhanced development and root growth of fig plants (Ficus carica). In: Nanotechnology 2013. Bio sensors, instruments, medical, environment and energy technical proceedings of the 2013 NSTI Nanotechnology Conference and Expo. Boston: Nano Science and Technology Institute; 2013. p. 167-170.

151. Khodakovskaya MV, de Silva K, Nedosekin DA, Dervishi E, Biris AS, Shashkov EV, Galanzha El, Zharov VP. Complex genetic, photothermal, 
and photoacoustic analysis of nanoparticle-plant interactions. Proc Natl Acad Sci. 2011;108:1028-33.

152. Flores D, Chacón R, Alvarado L, Schmidt A, Alvarado C, Chaves J. Effect of using two different types of carbon nanotubes for blackberry (Rubus adenotrichos) in vitro plant rooting. Growth Histol AJPS. 2014;05:3510-8.

153. Hao Y, Yang X, Shi Y, Xing J, Marowitch J, Chen J, Chen J. FITC delivery into plant cells using magnetic single-walled carbon nanotubes. J Nanosci Nanotechnol. 2012;12:6287-93.

154. Khodakovskaya M, Dervishi E, Mahmood M, Xu Y, Li Z, Watanabe F, Biris AS. Carbon nanotubes are able to penetrate plant seed coat and dramatically affect seed germination and plant growth. ACS Nano. 2009;3:3221-7.

155. Biris AS, Khodakovskaya MV. Method of using carbon nanotubes to affect seed germination and plant growth. Patent US20120233725.

156. Nair R, Mohamed MS, Gao W, Maekawa T, Yoshida Y, Ajayan PM, Kumar DS. Effect of carbon nanomaterials on the germination and growth of rice plants. J Nanosci Nanotechnol. 2012;12:2212-20.

157. Mondal A, Basu R, Das S, Nandy P. Beneficial role of carbon nanotubes on mustard plant growth: an agricultural prospect. J Nanopart Res. 2011;13:4519-28.

158. Lin D, Xing B. Phytotoxicity of nanoparticles: inhibition of seed germination and root growth. Environ Pollut. 2007;150:243-50.

159. Wang X, Han H, Liu X, Gu X, Chen K, Lu D. Multi-walled carbon nanotubes can enhance root elongation of wheat (Triticum aestivum) plants. J Nanopart Res. 2012;14:841.

160. Ghodake G, Seo YD, Park D, Lee DS. Phytotoxicity of carbon nanotubes assessed by Brassica juncea and Phaseolus mungo. J Nanoelectron Optoelectron. 2010;5:157-60.

161. Murashige T, Skoog F. A Revised Medium for Rapid Growth and Bio Assays with Tobacco Tissue Cultures. Physiol Plant. 1962;15:473-97.

162. Miralles $P$, Church TL, Harris AT. Toxicity, uptake, and translocation of engineered nanomaterials in vascular plants. Environ Sci Technol. 2012;46:9224-39.

163. Lin C, Fugetsu B, Su Y, Watari F. Studies on toxicity of multi-walled carbon nanotubes on Arabidopsis T87 suspension cells. J Hazard Mater. 2009;170:578-83.

164. Tan X, Lin C, Fugetsu B. Studies on toxicity of multi-walled carbon nanotubes on suspension rice cells. Carbon. 2009;47:3479-87.

165. Khodakovskaya M, de Silva K, Biris AS, Dervishi E, Villagarcia H. Carbon nanotubes induce growth enhancement of tobacco cells. ACS Nano. 2012;6:2128-35

166. Villagarcia H, Dervishi E, de Silva K, Biris AS, Khodakovskaya MV. Surface chemistry of carbon nanotubes impacts the growth and expression of water channel protein in tomato plants. Small. 2012;8:2328-34.

167. Khodakovskaya MV, Kim B, Kim JN, Alimohammadi M, Dervishi E, Mustafa T, Cernigla CE. Carbon nanotubes as plant growth regulators: effects on tomato growth, reproductive system, and soil microbial community. Small. 2013;9:115-23.

168. Kasel D, Bradford SA, Šimunek J, Pütz T, Vereecken H, Klumpp E. Limited transport of functionalized multi-walled carbon nanotubes in two natural soils. Environ Pollut. 2013;180:152-8.

169. Wild E, Jones KC. Novel method for the direct visualization of in vivo nanomaterials and chemical interactions in plants. Environ Sci Technol. 2009:43:5290-4

170. Chen G, Qiu J, Liu Y, Jiang R, Cai S, Liu Y, Zhu F, Zeng F, Luan T, Ouyang G. Carbon nanotubes act as contaminant carriers and translocate within plants. Sci Rep. 2015;5:15682.

171. Larue C, Pinault M, Czarny B, Georgin D, Jaillard D, Bendiab N, MayneL'Hermite M, Taran F, Dive V, Carrière M. Quantitative evaluation of multi-walled carbon nanotube uptake in wheat and rapeseed. J Hazard Mater. 2012;227:155-63.

172. Zhang M, Gao B, Chen J, Li Y, Zhang M, Gao B, Chen J, Li Y. Effects of graphene on seed germination and seedling growth. J Nanopart Res. 2015;17:78.

173. Liu S, Wei H, Li Z, Li S, Yan H, He Y, Tian Z. Effects of graphene on gersmination and seedling morphology in rice. J Nanosci Nanotechnol. 2015;15:2695-701.

174. Hu X, Zhou Q. Novel hydrated graphene ribbon unexpectedly promotes aged seed germination and root differentiation. Sci Rep. 2014;4:3782.
175. Begum P, Ikhtiari R, Fugetsu B. Graphene phytotoxicity in the seedling stage of cabbage, tomato, red spinach, and lettuce. Carbon. 2011;49:3907-19.

176. Anjum NA, Singh N, Singh MK, Shah ZA, Duarte AC, Pereira E, Ahmad I. Single-bilayer graphene oxide sheet tolerance and glutathione redox system significance assessment in faba bean (Vicia faba L.). J Nanopart Res. 2013;15:1770.

177. Anjum NA, Singh N, Singh MK, Sayeed I, Duarte AC, Pereira E, Ahmad I. Single-bilayer graphene oxide sheet impacts and underlying potential mechanism assessment in germinating faba bean (Vicia faba L.). Sci Total Environ. 2014:472:834-41.

178. Chung H, Kim MJ, Ko K, Kim JH, Kwon H, Hong I, Park N, Lee S, Kim W. Effects of graphene oxides on soil enzyme activity and microbial biomass. Sci Total Environ. 2015;514:307-13.

179. Hu X, Kang J, Lu K, Zhou R, Mu L, Zhou Q, Hu X, Kang J, Lu K, Zhou R, $\mathrm{Mu} \mathrm{L}$, Zhou Q. Graphene oxide amplifies the phytotoxicity of arsenic in wheat. Sci Rep. 2014;4:6122.

180. Hu X, Lu K, Mu L, Kang J, Zhou Q. Interactions between graphene oxide and plant cells: regulation of cell morphology, uptake, organelle damage, oxidative effects and metabolic disorders. Carbon. 2014;80:665-76.

181. Nogueira PFM, Nakabayashi D, Zucolotto V. The effects of graphene oxide on green algae Raphidocelis subcapitata. Aquat Toxicol. 2015;166:29-35.

182. Gottschalk F, Sonderer T, Scholz RW, Nowack B. Modeled environmental concentrations of engineered nanomaterials (TiO(2), ZnO, Ag, CNT, Fullerenes) for different regions. Environ Sci Technol. 2009;43:9216-22.

183. Zhang L, Petersen EJ, Habteselassie MY, Mao L, Huang Q. Degradation of multiwall carbon nanotubes by bacteria. Environ Pollut. 2013;181:335-9.

184. Kotchey GP, Zhao Y, Kagan VE, Star A. Peroxidase-mediated biodegradation of carbon nanotubes in vitro and in vivo. Adv Drug Deliv Rev. 2013;65:1921-32.

185. Sarma SJ, Bhattacharya I, Brar SK, Tyagi RD, Surampalli RY. Carbon nanotube-bioaccumulation and recent advances in environmental monitoring. Crit Rev Environ Sci Technol. 2015:45:905-38.

186. Klaine SJ, Alvarez PJ, Batley GE, Fernandes TF, Handy RD, Lyon DY, Mahendra S, McLaughlin MJ, Lead JR. Nanomaterials in the environment: behaviour, fate, bioavailability and effects. Environ Toxicol Chem. 2008;27:1825.

187. Serag MF, Kaji N, Gaillard C, Okamoto Y, Terasaka K, Jabasini M, Tokeshi M, Mizukami H, Bianco A, Baba Y. Trafficking and subcellular localization of multiwalled carbon nanotubes in plant cells. ACS Nano. 2011;5:493-9.

188. Irin F, Shrestha B, Cañas JE, Saed MA, Green MJ. Detection of carbon nanotubes in biological samples through microwave-induced heating. Carbon. 2012;50:4441-9.

189. Green MM, Irin F, Cañas J, Saed M. Detection of Carbon Nanotubes by Microwave-Induced Heating. Patent US 20130259085 A1.

190. Miralles P, Johnson E, Church TL, Harris AT. Multiwalled carbon nanotubes in alfalfa and wheat: toxicology and uptake. J R Soc Interface. 2012;9:3514-27.

191. Srivastava A, Rao DP. Enhancement of seed germination and plant growth of wheat, maize, penut and garlic using multiwalled carbon nanotubes. Eur Chem Bull. 2014;3:502-4.

192. Jiang Y, Hua Z, Zhao Y, Liu Q, Wang F, Zhang Q. The effect of carbon nanotubes on rice seed germination and root growth. In: Proceedings of the 2012 International Conference on Applied Biotechnology (ICAB 2012). Berlin: Springer. 2012. p. 1207-1212.

193. Haghighi M, Teixeira da Silva JA. The effect of carbon nanotubes on the seed germination and seedling growth of four vegetable species. $J$ Crop Sci Biotechnol. 2014;17:201-8.

194. Larue C, Pinault M, Czarny B, Georgin D, Jaillard D, Bendiab N, MayneL'Hermite M, Taran F, Dive V, Carrière M. Quantitative evaluation of multi-walled carbon nanotube uptake in wheat and rapeseed. J Hazard Mater. 2012;227-228:155-63.

195. Ghorbanpour M, Hadian J. Multi-walled carbon nanotubes stimulate callus induction, secondary metabolites biosynthesis and antioxidant capacity in medicinal plant Satureja khuzestanica grown in vitro. Carbon. 2015;94:749-59.

196. Tan X, Fugetsu B. Multi-walled carbon nanotubes interact with cultured rice cells: evidence of a self-defense response. J Biomed Nanotechnol. 2007;3:285-8. 
197. Tripathi S, Sonkar SK, Sarkar S. Growth stimulation of gram (Cicer arietinum) plant by water soluble carbon nanotubes. Nanoscale. 2011;3:1176.

198. Liang T, Yin Q, Zhang Y, Wang B, Guo W, Wang J, Xie J. Effects of carbon nanoparticles application on the growth, physiological characteristics and nutrient accumulation in tobacco plants. J Food Agric Environ. 2013;11:954-8.

199. Voleti R, Wait DA. Effect of carbon nanotubes on plant growth and gas exchange using Arabidopsis thaliana. In: Technical proceedings of the 2014 nsti nanotechnology conference and expo. Cambridge: NSTINanotech. 2014; p. 3.
200. Wang B, Liang T, Zhang Y, Zhou H, Yin Q, Zhang S. Effects of nano-carbon sol on growth, development, nutrient absorption and accumulation of flue-cured tobacco. Tob Sci Technol. 2013;72-86.

201. Yang J, Liang T, Li H, Yin Q, Zhang Y, Zhou H, Zhang S. Effects of nanocarbon sol on physiological characteristics of root system and potassium absorption of flue-cured tobacco. Tob Sci Technol. 2015;48:7-11.

\section{Submit your manuscript to a SpringerOpen ${ }^{\circ}$ journal and benefit from:}

- Convenient online submission

\section{- Rigorous peer review}

- Immediate publication on acceptance

- Open access: articles freely available online

- High visibility within the field

- Retaining the copyright to your article 